DIW BERLIN

Discussion

Papers

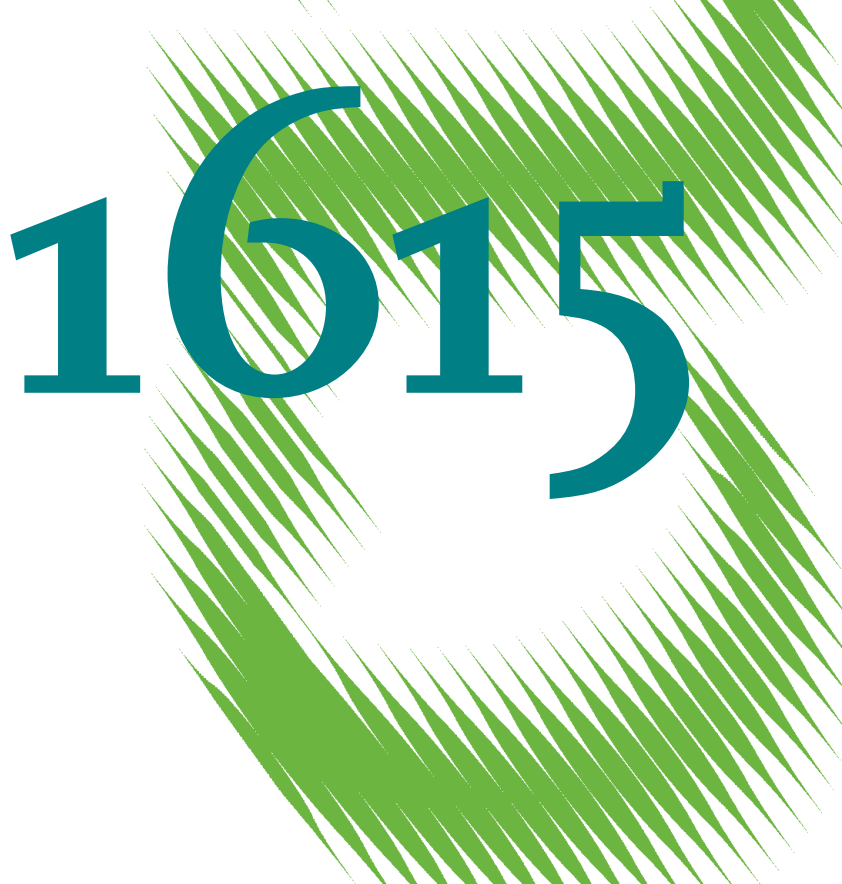

Financial Literacy:

Thai Middle Class Women Do Not

Lag behind 
Opinions expressed in this paper are those of the author(s) and do not necessarily reflect views of the institute.

IMPRESSUM

(C) DIW Berlin, 2016

DIW Berlin

German Institute for Economic Research

Mohrenstr. 58

10117 Berlin

Tel. +49 (30) $89789-0$

Fax +49 (30) $89789-200$

http://www.diw.de

ISSN electronic edition 1619-4535

Papers can be downloaded free of charge from the DIW Berlin website:

http://www.diw.de/discussionpapers

Discussion Papers of DIW Berlin are indexed in RePEc and SSRN:

http://ideas.repec.org/s/diw/diwwpp.html

http://www.ssrn.com/link/DIW-Berlin-German-Inst-Econ-Res.html 


\title{
Financial literacy: \\ Thai middle class women do not lag behind
}

\author{
Antonia Grohmann, Olaf Hübler, Roy Kouwenberg and Lukas Menkhoff
}

\begin{abstract}
This research studies the stylized fact of a "gender gap" in that women tend to have lower financial literacy than men. Our data which samples middle-class people from Bangkok does not show a gender gap. This result is not explained by men's low financial literacy, nor by women's high income and good education. Rather, it seems influenced by country characteristics on general gender equality and finance-related equality, such as little gender gaps regarding pupils' mathematics abilities or secondary school enrollment, and women's strong role in financial affairs. This may indicate ways to reduce the gender gap in financial literacy elsewhere.
\end{abstract}

JEL-Classification: $\quad$ D 14 (personal finance), J 16 (economics of gender), D 91 (intertemporal household choice)

Keywords: $\quad$ financial literacy, financial behavior, gender gap, individual characteristics, societal norms, Thailand

October 2016

We would like to thank for helpful comments participants at several workshops and the German Economic Association Annual Meeting in Hamburg, in particular Tabea Bucher-Koenen, Marcela Ibanez-Diaz, Lena Jaroczek, Stephan Klasen, Kristina Schluessler, David Schröder, the Editors, an Associate Editor and two anonymous referees. Financial support by the German Research Foundation (DFG, grant RTG 1723) is gratefully acknowledged. All personal information that would allow the identification of any person or person(s) described in the article has been removed.

Antonia Grohmann, German Institute for Economic Research (DIW Berlin), 10108 Berlin, Germany, and Leibniz University Hannover; agrohmann@diw.de.

Olaf Hübler, Leibniz University Hannover, Department of Economics, Königsworther Platz 1, 30167 Hannover, Germany; huebler@ewifo.uni-hannover.de.

Roy Kouwenberg, Mahidol University, College of Management, 69 Vipawadee Rangsit Road Samsennai, Phayathai District, Bangkok 10400, Thailand, and Erasmus University Rotterdam; roy.kou@mahidol.ac.th.

Lukas Menkhoff, German Institute for Economic Research (DIW Berlin), 10108 Berlin, Germany, Humboldt University Berlin and Leibniz University Hannover; Imenkhoff@diw.de. 



\section{Financial literacy: Thai middle class women do not lag behind}

\section{Introduction}

People have to make financial decisions with far reaching consequences in various domains of their life. They decide whether to save, how to invest their assets, whether and which kind of debt they take, which insurance to buy and how to deal with retirement savings (Campbell 2006). In some contrast to the importance and frequency of these decisions, many people do not seem to be well equipped to master these challenges. One widespread deficiency, of particular interest to us, is their lack of financial literacy, which is worse among women than men.

As the relatively low financial literacy of women compared to men has been reported in many studies (survey by Lusardi and Mitchell, 2014), Bucher-Koenen et al. (2014) coin this common finding the "gender gap" in financial literacy. Comparable evidence on this gap has been recently provided by a global survey on financial literacy. The results of Klapper et al. (2015) confirm that the degree of financial literacy is indeed higher for men in 135 out of 144 countries.

In contrast to this well documented gender gap in financial literacy, there is much less insight about its origins. Only a few studies use detailed data to dig deeper (see the later literature review). These studies tend to argue along three lines: first, the gender gap may be a phenomenon caused by lower education and income of women compared to men. Second, the gender gap may be due to less experience of women with financial affairs as men are more often responsible for financial issues. Third, the gender gap may reflect the specific, disadvantaged role of women in society as indicated by the lack of a gender gap in formerly socialist societies where gender equality was a formal principle. Overall, these arguments indicate forces towards reducing the gender gap but they do not fully explain why even welleducated women lag behind men in their degree of financial literacy (Halko et al., 2012, Mahdavi and Horton, 2014).

We complement the literature in this field by examining a group of middle class people from Thailand. Following the argument of Campbell (2006), financial literacy for this group is particularly important as financial affairs are in flux. While this group has increasing demand for financial products, supply of financial services is rapidly changing and becoming more 
sophisticated. Hence, we do not expect that a kind of rational inattention to financial affairs will drive behavior.

Regarding the gender gap we note that Thai women play a visible role in public and private affairs, and that well-educated middle class women seem to be as self-confident as their counterparts in advanced economies. However, such aspects may reduce but do not necessarily eliminate the gender gap in financial literacy.

Surprisingly, we do not find in this sample that women lag behind men regarding financial literacy. This result is not explained by differences in education, income or responsibility for financial affairs. Thus it is the first result documenting robust gender equality at a higher level of financial literacy, whereas evidence from formerly socialist countries shows equality at a low level of financial literacy (Klapper and Panos, 2011). This new evidence provides further insights into possible determinants of the gender gap and what policy could do to reduce it.

Why do we get this result? We see three possible explanations for this missing gender gap: a different study design, a different sample composition and a different country. Regarding the study design we are conventional by purpose, as we show below (Sections 3 and 4), so the explanation is unlikely to be found here. Regarding the sample composition we differ from most studies which aim for samples which are representative of the adult population. We show, however, that our specific sample (good education, high income and responsibility for financial decisions) does not drive the results (Section 5). Finally, regarding the country, we base our study in Thailand, which is culturally different from Western societies, which have mostly been studied so far. Our result suggests that "the country" is the most likely explanation for our unusual finding. Gender equality in broad measures and regarding finance-specific information seems to be supportive for a small gender gap in financial literacy. These finance-specific country characteristics include gender-equal numeracy and the responsibility of women for financial affairs (Section 6). More broadly speaking, this indicates to us that the financial literacy gender gap may be related to the specific role that women play in society.

In order to enable an analysis of gender-related financial literacy, we conduct a specifically designed questionnaire survey. This survey study covers 530 middle-class people from Bangkok and is described in detail in the data section below (Section 3). Crucially, this survey contains information about participants' socio-demographic situation, their biographical background, their financial literacy and financial decisions. This same survey has been used before by Grohmann et al. (2014) to examine the impact of financial literacy in the 
middle class; however, that paper does not focus on gender issues, nor on a gender gap. Thus we extend earlier results and demonstrate the relevance of financial literacy for good financial behavior by showing in IV-regressions that financial literacy does explain financial behavior whereas gender does not (Section 7 and Appendix).

Our result has an obvious policy implication as the commonly found gender gap in financial affairs seems to be entrenched in country-specific norms (the relation between gender differences and cultural background is also touched upon in Croson and Gneezy, 2009). If indeed country characteristics are important, this suggests that addressing such background determinants of financial behavior can improve outcomes of financial literacy trainings, which have often been disappointing (Fernandes et al., 2014). One could argue that financial literacy trainings should not only transfer knowledge on finance, but also need to go deeper and awaken an interest in financial matters along with a sense of financial responsibility. The case of Thailand indicates that a society where women - relative to men have good finance-specific abilities (i.e. numeracy) and are involved in financial affairs (due to financial responsibility in the household and labor market participation) contributes to reducing the gender gap in financial literacy and financial behavior. Improving these characteristics also indicate starting points for policy measures in general.

\section{Literature on the gender gap in financial literacy}

The gender gap in financial literacy has been documented in two kinds of studies. First, there are country studies where gender is just one variable, significantly indicating that women have lower financial literacy than men. Second, there are a few studies examining the gender gap in more detail. We shortly discuss this literature and finally link it to models of an “optimal degree” of financial literacy.

Many country case studies documenting a gender gap in financial literacy are summarized in short by Lusardi and Mitchell (2014). One of the most striking common patterns is the finding that there are "large sex differences in financial literacy" (Lusardi and Mitchell, 2014), with women being at a disadvantage. This finding also applies to studies with a focus on developing countries summarized as "women tend to have less financial literacy" in $\mathrm{Xu}$ and Zia (2012). However, these studies also document that the degree of financial literacy is positively related to income, education and financial responsibility, so that a gender gap in financial literacy may be in fact reflecting a gap in income, etc. Consequently, an analysis of the gender gap in financial literacy should control for these other variables. 
In contrast to a large number of country studies, two papers on Russia and East Germany (Klapper and Panos, 2011, Bucher-Koenen and Lamla, 2014) do not find a gender gap, indicating that former Eastern European societies may have something in common. However, different from our sample, the level of financial literacy is low for both women and men. Thus it is not clear whether one can really learn from this experience for current policies.

A shortcoming of this line of literature has been its heterogeneity, such as the use of different measures of financial literacy across countries, measuring at different points in time with different samples, etc. Any concerns regarding comparability or selection issues have been eliminated by a recently released dataset (McGraw Hill Financial Global FinLit Survey data, 2015) which uses a unified approach in 143 countries in the world. Figure 1 shows the difference of male minus female financial literacy across countries. This further corroborates the stylized fact of a gender gap in financial literacy. This is not a universal law, however, because in about $10 \%$ of countries covered women have a higher degree of financial literacy than men. As much of the distribution of the gender gap is around a difference of zero, if one assumes a normal distribution of financial literacy for men and women across all countries, this leads to about $40 \%$ of countries with no significant difference, between men and women. At the same time, there are no countries where women significantly outperform men and still $60 \%$ of countries have a significant gender gap in financial literacy.

$<$ Figure 1 about here $>$

Whereas gender is usually just a control variable (Fernandes et al., 2014), there are only a few papers specifically examining women. Lusardi and Mitchell (2008) find that in particular older women show a severe lack of financial literacy. A study by Chen and Volpe (2002) also finds a gender gap among highly educated U.S. college students. Mahdavi and Horton (2014) show that even amongst the most educated women, financial literacy leaves room for improvement, while other studies focus on specific issues, e.g. the take-up of mortgage loans with interest rate risk (Do and Paley, 2013). Bucher-Koenen et al. (2014) stand out in the literature as they analyze possible explanations for the gender gap. They discuss the effects of income, education and wealth for the gender gap and find that the gender gap is reduced by half, but does not disappear when controlling for these factors. Hsu (2015) argues that the financial literacy between men and women is caused by specialization in the intrahousehold production function. They find that the financial literacy of women increases as they approach widowhood. Filipiak and Walle (2015) provide evidence for cultural determination of the gender gap when comparing, financial literacy of women living in matrilineal and patrilineal societies in India. 
In those cases where women are different in their socio-demographic characteristics from men, one may think about a link of these empirical findings to models of an "optimal degree of financial literacy” (Lusardi et al., 2015). These models assume a rational stance on financial issues so that individuals optimize their "investment” in financial literacy. Following this reasoning, the investment will be lower if a person gains less and if costs are relatively high. Accordingly, investment is lower for younger people with less financial assets, for those with lower income, in countries where retirement savings are publicly organized, and those with less education (and thus higher costs to learn something new). Finally, there is of course the possibility that some people are less interested in financial affairs. Whereas there is some evidence for many of these relationships and financial literacy, this line of theory does not explain the gender gap, if the respective variables (age, income etc.) are controlled for.

\section{Sample collection and characteristics}

This section describes the data in general, that is, the conduct of the survey (3.1) and participants’ socio-demographic characteristics (3.2). Characteristics are presented separately for women and men.

\subsection{Conduct of the survey}

The data used in this paper was collected during a survey in Bangkok at the end of 2012. The sample consists of 530 respondents and was collected using street interviews throughout Bangkok. The survey was conducted by a survey company, using a questionnaire designed by the research team. The questionnaire was pre-tested using respondents from the target group and the survey company gave feedback based on previous experience. As we aim to cover people with a number of different levels of wealth, income, employment status and family backgrounds, interviews were conducted in commercial as well as residential areas of Bangkok. Areas were chosen before the start of the survey and each area was covered by a team consisting of three or four interviewers. Interviews, however, were conducted on a one to one basis. Each interviewer had previous survey experience and was trained on this specific questionnaire. Respondents answered questions orally and interviewers noted the answers down in the questionnaire.

In order to counteract potential sample bias problems with this form of surveying, a number of precautions were taken and respondents were pre-selected based on four different criteria. First, as this study explicitly aims to study the urban middle-class, income had to be over 15,000 baht a month, which is the starting salary for a recent graduate. According to the 
Thai Office of National Statistics, 29\% of Bangkok residents earn this amount or more. Second, respondents had to be at least 18 years and not over 60 as to be allowed to make their own financial decisions, but not to have started retirement. Third, respondents had to be resident in Bangkok and fourth, and most importantly for the purpose of this paper, they had to be responsible for their own or their household's financial decisions.

Thus, we basically got a convenience sample where interviewers aimed for a balanced sample with respect to gender and aimed for diversity regarding age. If the person approached did not meet the above mentioned four requirements, the interview was discontinued after the preliminary questions. Among these four criteria only the first one (too low income) led to a larger number of discontinued interviews, so that about 31\% of those approached failed initial screening. That implies that the criteria being resident in Bangkok, being responsible for financial affairs and consenting being interviewed were usually met. The interview was conducted verbally, while the interviewer noted responses on paper questionnaires. Each interview only took about 20 minutes.

\subsection{Socio-demographic characteristics of women and men}

As the survey focuses on the urban middle-class in an emerging economy it is unsurprising that our sample is young and well educated. The average age is 34 years and 64\% of our respondents have a bachelor's degree and a further $15 \%$ have vocational training. Table 1 shows these and more summary statistics broken down by gender. The table's last column shows $p$-values for a $t$-test comparing men and women.

$<$ Table 1 about here>

At an average income of just under 26,800 baht a month (approximately 600 US dollar), earnings of our sample are considerably higher than the Bangkok average, which was 17,000 baht a month in 2011 (source: National Statistics Office). About half of our respondents are married. The average number of three adults per households is typical for Bangkok as often two or three generations live together. Despite this somewhat traditional behavior, the low average number of less than one child per household reflects the modern life-style of middleclass people.

We complement standard socio-demographic characteristics with numeracy and risk attitude, two variables of particular interest when analyzing financial literacy as these may also influence financial behavior (Agarwal and Mazumder, 2013). When we turn to our measure of numeracy, which is compiled by answering four math questions (for details see in the Appendix Table A1), we get average values at about 3.5. Regarding risk aversion, we rely on a 
survey based question (see Table A1). This simple measure of risk attitude asks respondents to place themselves on a scale between zero and ten, with zero meaning "unwilling to take risk" and ten meaning "fully prepared to take risk". This measure has been used in previous studies and has been shown to be closely correlated with experimental measures of risk aversion (Dohmen et al. 2011, Hardeweg et al. 2013). In order to make interpretation easier we reverse the scale and use a zero to one scale, which thus provides a measure of self-assessed risk aversion on a scale between 0 and 1 .

Finally, Table 1 reports information about the amount of financial assets held by participants. Since we only required respondents to give their asset value in categories, we created three dummies for the value of assets, namely high, medium and low. Women are slightly more likely to be in the lowest asset group (54\%, versus $47 \%$ for men).

As we can see, men and women in our sample are the same on average with respect to most socio-demographic variables, such as age, household composition, education and numeracy. However, there also are marked differences between the sexes: women show more risk aversion and also have lower incomes than men, despite requiring a minimum income of above 15,000 baht to participate in the survey.

\section{$4 \quad$ Financial literacy of women and men}

In this section we show that women in our sample are not less financially literate than men, irrespective of the financial literacy measure being used (Section 4.1). Thereafter, regressions demonstrate that a higher degree of financial literacy is related to conventional variables, such as better education, more income, etc., independent of gender (Section 4.2).

\subsection{Information from various financial literacy measures}

The survey includes four questions designed to measure financial literacy. The first three questions were first used in the US Health and Retirement Survey in 2004 by Lusardi and Mitchell (2007) and now have become standard items to measure financial literacy. Hence these three questions have been widely used on a number of different groups from a large number of countries. This enables direct comparisons across countries and social groups. We supplement these three standard questions with a fourth question introduced by Cole et al. (2011). Financial literacy questions are often argued to be too focused on numeracy. This argument has also been made by Carpena et al. (2011), who supplement questions on financial numeracy with questions on financial awareness, financial attitudes and perceptions. We therefore test our respondents' institutional knowledge by asking them to name as many 
foreign banks that operate in Bangkok as possible. Many of such banks are active also in retail banking, including credit card business, since the Asian crisis of 1997. Exact questions can be found in Table 2.

$<$ Table 2 about here $>$

A number of different ways have been used in the literature to form financial literacy scores. Here, we focus on two methods; firstly we simply award one point for each correct answer given, so that all questions are weighted equally. This gives us three different scores, i)financial literacy out of 3, ii) financial literacy out of 4 and iii) a combination out of the financial literacy score and 0.25 point awarded for one foreign bank named. Secondly we use factor analysis and use the first factor as a measure for financial literacy. In addition to dummies that take the value of one for each correct question, we also include variables that are unity if the respondent answers “I don’t know” (van Rooij et al. 2011). Furthermore, the number of foreign banks that someone can name is also included in the factor analysis.

Dummies for each question, along with the four aggregate scores are reported in Table 2, broken down by gender. From the $t$-test result we can see that there is no significant difference in the level of financial literacy between men and women. This holds for all measures of financial literacy documented in Table 2. The share of correct answers is better than measured for the U.S., but below the share measured in either the Netherlands or Germany (BucherKoenen et al., 2014). The main shortcoming of the Bangkok sample is in the response to item three, which measures diversification, probably because the share of stock owners is below that found in advanced economies.

Finally, Bucher-Koenen et al. (2014) mention that in surveys from many countries women tend to report that they do not know the answer on financial literacy items more often than men. We show at the bottom of Table 2 that there is no such difference in our sample. Moreover, the frequency of "do not know" responses in our sample is comparable to men in other studies, and thus not unusually high.

\subsection{Financial literacy and socio-demographic information}

As it is known that the degree of financial literacy is related to (determined by) several socio-demographic characteristics, we test these relations for our sample in four steps. First, we run a regression explaining financial literacy by four standard socio-demographic characteristics, i.e. gender, age, income and education. We find that higher income and better education are significantly related to better financial literacy (see Table 3, column 1). 
Second, we add to this specification risk aversion as fifth variable which can also be seen as proxy for cognitive ability (Dohmen et al., 2010) or as a personal trait which may motivate an interest in financial affairs. We find that risk aversion is - as expected negatively related to the degree of financial literacy (see column 2). Next, we split the sample according to gender and find that the relations roughly hold for the separated samples (see columns 3 and 4). In the fifth column we add a biographical information which is different for women and men, i.e. mother's education, and find no significant relation (see the Appendix for further information on education of the mother and other biographical information). Overall, the relations between socio-demographic variables and the degree of financial literacy are in line with the literature, confirming the usefulness of the data, and do not differ by gender. Further, the results confirm that there is no gender gap in financial literacy in the Thai middle class, even after controlling for individual differences in income, education and risk aversion.

\section{Sample composition and the gender gap}

To find a possible explanation for the missing gender gap among the Thai middle class we now investigate the sample composition in more depth: we look at further sample splits within our dataset (5.1) and select groups similar to ours from other countries (5.2).

\subsection{Sample composition: further splits of our sample}

Our sample is different from most literature, because the sample is not representative of the adult population but selective on purpose. Thus, people in our sample are, relative to Thailand or even Bangkok, well-educated and economically well off. Relative to the rest of the world, our sample is young. All of these characteristics may contribute to reducing the gender gap in financial literacy, although there has been no indication so far from the multivariate regression in Section 4.2.

Regarding education, income and age, earlier studies do not really show large differences in a gender gap between groups that are different along these lines, such as uneducated versus well educated people, etc. (Bucher-Koenen et al., 2014). Nevertheless, we split our sample in the three mentioned dimensions to see whether this makes a difference. We find that none of these splits reveal a systematic and significant influence on the gender gap (see Table A2 in the Appendix). This suggests that the examined characteristics of the Bangkok middle-class sample are not driving the result. 


\subsection{Sample composition: selecting groups from other countries' data sets}

Next, we take representative samples from the populations in the U.S., the Netherlands and Germany and aim for a set of selection criteria similar to our survey of the Thai middle class in Bangkok. Then we analyze whether these selection criteria contribute to reducing the measured gender gap. A first step into this direction is already implicitly provided by BucherKoehnen et al. (2014) who note that the gender gap regarding the degree of financial literacy in the German SAVE data set is roughly reduced by half when controlling for sociodemographic characteristics, but still significant.

In order to examine these effects more systematically across three additional datasets, we aim for largely identical regressions explaining the degree of financial literacy, similar to our approach in Section 4.2. The control variables in these regressions include gender, age, education, income and risk aversion. We find useful variables for these items in all three data sets being considered. In detail, age is also added as a squared term and we use a dummy variable for education distinguishing advanced from basic education (the definition varies between databases). Income is measured in logs and as we aim to study people with higher incomes, i.e. analogous to the top 29\% of income distribution as in Bangkok, the exact cut-offs vary between countries. Finally, risk aversion is controlled for but measured differently, depending on the specific risk attitude question(s) available in the dataset. Results show that the gender gap remains basically unaffected by any effort to shape the underlying sample for the three countries where we have access to data sets.

For the U.S. we take survey data from the American Life Panel (ALP), provided by the RAND Corporation. Our ALP sample with financial literacy data covers more than 3,200 persons and shows a clear and highly significant gender gap at the disadvantage of women (Table 4). When we reduce the sample to make it more similar to our Thai data by reducing age and increasing minimum income, the gender gap remains unaffected. A maximum age of 60 years equals the Thai case but a reduction to even 50 years is necessary to get a similar average age as in the Thai case.

\section{$<$ Table 4 about here $>$}

We also repeat this procedure for representative samples from the Netherlands and Germany (in the Appendix Table A3 and Table A4, respectively). Overall, we see that the socio-demographic regressions always show well-known relationships with financial literacy: older age, better education and higher income are associated with higher financial literacy, whereas the relationship with risk aversion is unclear. We conclude that the socio- 
demographic characteristics of our sample from Bangkok cannot explain the missing gender gap.

\section{Country characteristics and the gender gap}

We here turn to the possible explanation of the gender gap that - so far not considered country characteristics may be the driving force. As an implication we first use information from two other samples in Thailand, which should provide results similar to our middle class sample (Section 6.1). Thereafter we analyze in large cross-country samples whether general cross-country characteristics (Section 6.2) or finance-specific characteristics (Section 6.3) may contribute to a consistent explanation.

\subsection{Information from other samples in Thailand}

If country characteristics are an important influence on the gender gap, the gap should be similar within a country across various groups. We confirm this hypothesis by comparing our results on the Bangkok middle class to two other surveys, one a more representative survey held country-wide and one from Thailand's poorest region, i.e. the Northeast.

The Bank of Thailand (2013) in cooperation with the National Statistics Office conducted a country-wide financial literacy survey in 2013, whose results are summarized in a report (access to the underlying data was not granted). The survey covered 10,627 persons from all regions in Thailand, with the aim to represent the entire population, although the 61.5\% share of female participants indicates that the sampling was not strictly representative. The financial literacy assessment is based on a set of questions about financial knowledge, behavior and attitudes, resulting in a score ranging from 0 to 22. The mean result for women is 12.8, for men 13.0 and overall 12.9. The gender gap of 0.2 points corresponds to $1.5 \%$, which is economically very small (tests of statistical significance are not reported). The interpretation in the document highlights the importance of income and education for the degree of financial literacy, whereas gender is not mentioned.

Another independent piece of information about financial literacy in Thailand comes from a survey in the rural Northeast whose general characteristics are described in Hardeweg et al. (2013), amongst others. There the median monthly income is about 4,000 baht compared to a minimum of 15,000 baht and a median of about 20,000 baht in the urban sample. The wave in 2013 includes the three basic Lusardi and Mitchell-items on financial literacy in the modified form as suggested by Cole et al. (2011). For the rural areas of the province Buri Ram, 745 households are covered and so form a representative sample for this area. The 
outcome of the financial literacy score is 1.56 for women and 1.61 for men, the difference being far from statistically significant. Scores are similar to those from our urban population as the "diversification" question is relatively simple and adjusted to the rural population which would not know much about stock investments. Regarding the two questions on "interest rates" and "inflation" the rural scores are below the urban ones, as expected for a less educated population. Finally, there is also no gender gap when we control for conventional sociodemographic characteristics as can be seen from the specifications (2) to (4) in Table 5 (column 1 repeats specification 2 from Table 4, for convenience).

\section{$<$ Table 5 about here $>$}

Overall, equality between women and men in financial literacy seems remarkably robust in Thailand, although the samples studied here are very different. This indicates that indeed some characteristic of the country may be responsible for this missing gender gap.

\subsection{Gender differences: general cross-country evidence}

In the following we analyze characteristics of Thailand, i.e. cultural or institutional characteristics, in relation to other countries, which may help understand the (missing) gender gap in financial literacy (see Prince, 1993). In this Section 6.2 we look at cross-country evidence referring to the situation of women in general, whereas more finance-specific evidence is examined in the following Section 6.3 (see Bertrand, 2011, on culture and gender stereotypes).

One may speculate that specific cultures or their societal norms, which emphasize equality between women and men, generally reduce the gender gap in society and as a byproduct also reduce the gender gap in financial literacy. We consult three of such types of information, i.e. the "gender equality index", the "masculinity index" and a "female leaders index”. Quite broad information is provided by the World Economic Forum’s Gender Equality Index (World Economic Forum Global Gender Gap Report, 2013). According to this index, however, Thailand performs not well in general gender equality (ranked 65) in comparison to Germany (ranked 14), the Netherlands (ranked 13) and the U.S. (ranked 23).

In order to provide more systematic cross-country evidence, we follow Guiso et al. (2008) and show regression results. The gender gap in financial literacy is explained by a constant term, by log GDP per capita and a gender-specific characteristic. Taking the gender equality index as our first gender-specific characteristic, the coefficient sign is unexpectedly positive and the R-squared is relatively low with $2 \%$ (see Table 6 , column 1 ). Inspecting the data, Arabic countries seem to be special in the sense that they tend to have a large gender gap 
in general but a relatively small one regarding financial literacy, indicating that they are different from other countries. Thus, excluding 11 Arabic countries from the sample leads to a higher R-squared and the expected coefficient sign, although it is still insignificant.

$<$ Table 6 about here $>$

We repeat these regressions also for the masculinity index. A less masculine society may be related to more equal roles of men and women in family and work-life, including a more equal responsibility for financial affairs. Taking the Hofstede $(1980,2001)$ index of the masculinity of a society, we see that Thailand does indeed score low with a value of 34 on a range between 0 and 100. Results for the broad sample, however, presented in columns (3) and (4) show an unexpected significant coefficient sign. Obviously, the Hofstede masculinity index does not provide a good explanation for the gender gap in financial literacy. Finally, we look at the female leader index, which is measured as the percentage of legislators, senior officials and managers which are women and is collected by the World Bank (see columns 5 and 6). This has the expected sign and the regression excluding Arabic countries has a significant coefficient and a high R-square.

Overall, our regression results seem to point into the expected direction but not more. Obviously, just taking the raw estimation results may not do justice to heterogeneity in the world in these cross-country regressions. To demonstrate some potential for improvement in further work, we argue that the absolute gender gap in financial literacy may be less relevant from a policy perspective than the relative size of the gap. As in many Western societies the gender gap in financial literacy is high, but at a high level overall, the relative gap is small compared to poorer countries. Thus, taking a relative measure of gender gap in financial literacy and plotting this against the gender equality index leads to expected relation, i.e. that the more gender-equal societies tend to have smaller gender gaps in financial literacy (see Figure 2).

$<$ Figure 2 about here $>$

Overall, the (missing) gender gap in financial literacy does not seem to be well explained by broad indices of gender equality, masculinity or female leadership. In particular, masculinity does not really explain the relation of interest. Thus we search for more financespecific information.

\subsection{Gender differences: finance-specific cross-country evidence}

Regarding finance-specific gender differences in country characteristics we distinguish six kinds of information: (i) numeracy as an established basis for financial literacy because it 
seems difficult to understand financial concepts without solid mathematical foundations, (ii) education as a broader determinant of financial literacy, (iii) the composition of students according to study fields in a country, (iv) financial responsibility in various fields (see, e.g., Fonseca et al., 2012), (v) financial implications of female labor market participation (see Bucher-Koenen et al., 2014) and (vi) wage equality regarding gender.

Numeracy. Regarding numeracy, the recent PISA cross-country study provides information on our countries of interest (OECD, 2013). As numeracy is a precondition for financial literacy, we hypothesize that countries with a smaller gender gap in numeracy will have a smaller gender gap in financial literacy (see Japelli, 2010, on economic literacy). Indeed, taking the gender difference in the PISA math score, Thailand stands out as girls perform even better in the math test than boys. Moreover, Thailand is one of two countries out of about 30, where girls do better than boys in all dimensions during the surveys in 2003. In 2012, Thailand was one of only eight countries where girls do better than boys out of the 59 countries. In a related study, Guiso et al. (2008, p.1165) conclude “In more gender-equal societies, girls perform as well as boys in mathematics and much better than them in reading” which is the case in Thailand. However, the expected relationship is not significant on a world-wide level as regression results in Table 7, column 1 show.

$<$ Table 7 about here $>$

Education level. As numeracy seems to be related to financial literacy, one would expect the same relation for the broader measure of attainment, i.e. regarding the educational level. We also know that better education is related to a higher degree of financial literacy, so we expect that the gender gap in financial literacy is related (driven by) a gender gap in educational attainment, here proxied by enrollment in secondary education (enrollment rates for boys and girls in secondary school are published by the World Bank). The regression result in column 2 of Table 7 does indeed show the expected significant coefficient. Also the simple cross-country plot in Figure 3 (which does not control for GDP per capita) seems to strongly support the hypothesis.

$<$ Figure 3 about here $>$

Enrollment in study fields. Knowledge in financial affairs may be supported by the choice of certain study subjects and knowledge in these subjects indicates an interest in financial issues. The information about the share of female graduates in the fields of business, law and social science (published by the World Bank) is indeed related to the gender gap in financial literacy in the expected way (see column 3). As already discussed above, the results 
become stronger when we exclude countries that are members of the Arabic League. However, the coefficient is insignificant.

Financial responsibility. Regarding the characteristic of financial responsibility, one can plausibly assume that it is relevant for the degree of financial literacy. Reasons for such a relation may be self-selection of people with interest and ability into taking financial responsibility but also that financial literacy may be improved through exposure to financial issues (see Fonseca et al., 2012). It is revealing in this respect that during our sample screening questions, no one was rejected on the grounds of not being responsible for their own finances, demonstrating the strong role of Thai (middle class) women regarding financial issues.

Another piece of evidence in this direction is women's role in financial asset management companies (Beckmann and Menkhoff, 2008). Compared to the U.S., Germany and Italy, the share of female asset managers is much higher in Thailand (46\% compared to between $10 \%$ and $21 \%$ in the three other countries). Even more remarkable, these women are equally represented in leading positions in asset management firms in Thailand, whereas they are underrepresented in the three other countries studied in the paper, in two countries to a statistically significant degree. This picture is completed by the facts that female asset managers in Thailand - and only in Thailand - have the same level of responsibility for assets under management and work as many hours as their male counterparts. Overall, this provides evidence that Thai women have financial responsibility at home and in the professional domain.

Finally, there is some information about 15 Asian Pacific countries. A study published by Master Card informs about the share of women who are responsible for their financial affairs and this share is indeed negatively related to the gender gap in financial literacy in these countries. However, the coefficient is insignificant.

Labor market participation. A final indirect aspect of finance-related country characteristics stems from the labor market where gender equality has not been fully materialized yet (Goldin, 2014). Here we hypothesize that stronger participation of women leads to more responsibility for personal financial affairs, in line with the argument by BucherKoenen et al. (2014) that experience and learning seems to have an impact on financial literacy and its gender gap. Indeed, Thai female labor force participation stands at $64.3 \%$, which is considerably higher than in many Western countries, such as the U.S., the Netherlands and Germany (data published by ILO). Similarly, women in Thailand are more likely to be in full-time employment compared to their counterparts in other countries. 
However, despite its plausibility and evidence based on a selection of few countries, the hypothesis that labor market participation would reduce the gender gap in financial literacy does not hold in broad cross-country regressions. The regression results in column 5 of Table 7 show this.

Wage equality. An another indicator, Thailand scores high on the wage equality for similar work ranking (World Economic Forum, 2013, based on questionnaires answer by international executives). Youngsamart et al. (2010, p.426) conclude from their interviews with managers that the "consensus view was that there were no real barriers to promotion based on gender" and "little difference in the salaries paid to women or men". All this indicates that women have a relatively equal position in the Thai labor market. Again, the regression result provides an insignificant coefficient (see column 6).

All this suggests that women's role regarding finance-specific country characteristics, such as numeracy, education and financial responsibility helps to explain the missing gender gap in financial literacy for the case of Thailand, and the gender gap in financial literacy in general. However, the relations are often insignificant, so that more work is necessary to reveal the driving forces than our more illustrative regressions and plots.

\section{Financial behavior of women and men}

This paper is about the gender gap in financial literacy. However, evidence on the missing gender gap among the Thai middle class would be more relevant if this also translates into respective financial behavior. Therefore, we note here that the women in our sample do not make worse financial decisions than men (detailed information is provided in the Appendix).

\section{Conclusions}

The gender gap in financial literacy is a common finding in the literature (e.g., Lusardi and Mitchell, 2014). Many country studies have shown (with few exceptions) that the degree of financial literacy among women is lower than among men, and this finding holds no matter whether being controlled for socio-demographic characteristics or not.

Compared to these studies, we present a new and surprising finding. In our sample of 530 middle class people in Bangkok, we do not find a gender gap. Instead, women show the same high level of financial literacy as men, whatever specific measurement of financial literacy we choose. Moreover, this result is strengthened by the finding that women also show the same degree of informed financial behavior as men when we analyze their decision 
making. As our procedure is quite conventional for this literature and as the missing gender gap also holds in other samples from Thailand, we regard the data as credible. Therefore, there must be other reasons for our unconventional finding. Learning about these reasons provides information about possible ways to reduce the gender gap in other countries.

Regarding sample composition our analyses show that this does not explain the missing gender gap. Also regarding general country characteristics neither the degree of masculinity (see Hofstede, 1980, 2001) nor the World Economic Forum Gender Gap Index point towards a particularly small gender gap for Thailand. The case becomes clearer when we consider more finance-specific country characteristics, namely numeracy, relatedly good education and financial responsibility. In all these regards Thai women have a strong role compared to women in other countries.

This finding for Thailand indicates general lessons about the roots of a gender gap in financial affairs, in particular that the gender gap is embedded in broader societal norms. One may hypothesize that a society where women relative to men command over an equal degree of numeracy, have the same degree of financial responsibility and participation in the labor market, will also be a society with a smaller gender gap in financial literacy and financial behavior. It follows that financial literacy is to a large extent the consequence of gender role in society.

Whereas such role models seem difficult to influence, our study also indicates more optimistic aspects: first, the Thai case suggests that high levels of competency of women in financial affairs can be reached without achieving gender equality in all respects. Second, studies show that financial literacy can be trained and learned to some extent (Lusardi and Mitchell, 2014), so that the gender gap in financial literacy can also be reduced by such concrete measures.

For further research with a direct policy focus one may think about comprehensive cross-country studies to investigate which country factors can explain the often observed gender gap in financial literacy. Also studies examining the effectiveness of financial trainings with an emphasis on gender may provide helpful insights. 


\section{References}

Agarwal, Sumit and Bhashkar Mazumder (2013), Cognitive Abilities and Household Financial Decision Making, American Economic Journal: Applied Economics, 5, 193-207.

Andrews, D.W.K. (1999), Consistent Moment Selection Procedures for Generalized Method of Moments Estimation, Econometrica, 67, 543-564.

Bank of Thailand (2013), Thailand's Financial Literacy Survey Results, Bangkok.

Beckmann, Daniela and Lukas Menkhoff (2008), Will Women Be Women? Analyzing the Gender Difference among Financial Experts, Kyklos, 61, 364-384.

Behrman, Jere R., Olivia S. Mitchell, Cindy K. Soo and David Bravo (2012), How Financial Literacy Affects Household Wealth Accumulation, American Economic Review Papers and Proceedings, 102:3, 300-304.

Bertrand, Marianne (2011), New Perspectives on Gender, in: David Card and Orley Ashenfelter (eds.), Handbook of Labor Economics, Vol.4 Part B, 1545-1592.

Bucher-Koenen, Tabea and Bettina Lamla (2014), The Long Shadow of Socialism: On EastWest German Differences in Financial Literacy, MEA Discussion Paper 282-14, Munich.

Bucher-Koehnen, Tabea, Annamaria Lusardi, Rob Alessie and Maarten van Rooij (2014), How Financially Literate are Women? An Overview and New Insights, NBER Working Paper 20793.

Campbell, John Y. (2006), Household Finance, Journal of Finance, 61, 1553-1604.

Carpena, Fenella, Shawn Cole, Jeremy Shapiro and Bilal Zia (2011), Unpacking the Causal Chain of Financial Literacy, World Bank Policy Research Paper 5798.

Chen, Haiyang and Ronald P. Volpe (2002), Gender Differences in Personal Financial Literacy Among College Students, Financial Services Review, 11, 289-307.

Cole, Shawn, Thomas Sampson and Bilal Zia (2011), Prices or Knowledge? What Drives Demand for Financial Services in Emerging Markets? Journal of Finance, 66, 19331967.

Croson, Rachel and Uri Gneezy (2009), Gender Differences in Preferences, Journal of Economic Literature, 47, 448-474.

Do, Chau and Irina Paley (2013), Does Gender Affect Mortgage Choice? Evidence from the US, Feminist Economics, 19, 33-68.

Dohmen, Thomas, Armin Falk, David Huffmann, Uwe Sunde (2010), Are Risk Aversion and Time Preferences Related to Cognitive Ability, American Economic Review, 100, 12381260.

Dohmen, Thomas, Armin Falk, David Huffmann, Uwe Sunde, Jürgen Schupp, and Gert G. Wagner (2011), Individual Risk Attitudes: Measurement, Determinants and Behavioral Consequences, Journal of the European Economic Association, 9, 522-50.

Eckel, Catherine C., and Philip J. Grossman (2008), Men, Women and Risk Aversion: Experimental Evidence, In: Handbook of Experimental Results, Charles Plott, and Vernon Smith (eds.), Elsevier, New York.

Efron, Bradley, Trevor Hastie, Iain Johnstone, and Robert Tibshirani (2004), Least Angle Regression, Annals of Statistics, 32, 407-451.

Fernandes, Daniel, John G. Lynch Jr. and Richard G. Netemeyer (2014), Financial Literacy, Financial Education and Downstream Financial Behaviors, Management Science, 60, 1861-1883.

Fonseca, Raquel, Kathleen J. Mullen, Gema Zamarro and Julie Zissimopoulos (2012), What Explains the Gender Gap in Financial Literacy? The Role of Household Decision Making, Journal of Consumer Affairs, 46, 90-106. 
Filipiak, Ute and Yabibal Walle (2015), The Financial Literacy Gender Gap: A Question of Nature or Nurture, Courant Research Centre: Poverty, Equity and Growth Discussion Paper, No 176.

Gathergood, John (2012), Self-Control, Financial Literacy and Consumer Over-Indebtedness, Journal of Economic Psychology, 33, 590-602.

Goldin, Claudia (2014), A Grand Gender Convergence: Its Last Chapter, American Economic Review, 104, 1091-1119.

Grohmann, Antonia, Roy Kouwenberg and Lukas Menkhoff (2014), Financial Literacy and Its Consequences in the Emerging Middle Class, Kiel Working Paper 1943.

Guiso, Luigi, Ferdinando Monte, Paola Sapienza and Luigi Zingales (2008), Culture, Gender, and Math, Science, Vol. 320.

Gustman, Alan L., Thomas L. Steinmeier and Nahid Tabatabai (2012), Financial Knowledge and Financial Literacy at the Household Level, American Economic Review Papers and Proceedings, 102:3, 309-313.

Halko, Marja-Liisa, Markku Kaustia, Elias Alanko (2012), The Gender Effect in Risky Asset Holdings, Journal of Economic Behavior and Organization, 83, 66-81.

Hardeweg, Bernd, Lukas Menkhoff and Hermann Waibel (2013), Experimentally Validated Survey Evidence on Individual Risk Attitudes in Rural Thailand, Economic Development and Cultural Change, 61, 859-888.

Hofstede, Geert (1980), Culture's Consequences: International Differences in Work-Related Values, Sage Publications, Beverly Hills, CA.

Hsu, Joanne (2015), Ageing and Strategic Learning: The Impact of Spousal Incentives on Financial Literacy, Journal of Human Resources, forthcoming.

Hofstede, Geert (2001), Culture's Consequences: Comparing Values, Behaviors, Institutions, and Organizations Across Nations, Sage Publications, Thousand Oaks, CA.

Jappelli, Tullio (2010), Economic Literacy: An International Comparison, Economic Journal, 120, F429-F451.

Klapper, Leora, Annamaria Lusardi, Peter van Oudheusden, Financial Literacy Around the World: Insights from the Standards and Poor's Ratings Service Global Financial Literacy Survey, https://www.finlit.mhfi.com.

Klapper, Leora, and Georgios A. Panos (2011), Financial Literacy and Retirement Planning: The Russian Case, Journal of Pension Economics and Finance, 10, 599-618

Lusardi, Annamaria and Olivia S. Mitchell (2007), Baby Boomer Retirement Security: The Roles of Planning, Financial Literacy, and Housing Wealth, Journal of Monetary Economics, 54, 205-224.

Lusardi, Annamaria and Olivia S. Mitchell (2008), Planning and Financial Literacy: How Do Women Fare? American Economic Review Papers and Proceedings, 98:2, 413-417.

Lusardi, Annamaria and Olivia S. Mitchell (2014), The Economic Importance of Financial Literacy: Theory and Evidence, Journal of Economic Literature, 52, 5-44.

Lusardi, Annamaria, Pierre-Carl Michaud, Olivia Mitchell (2015), Optiaml Financial Knowledge and Wealth Inequality, Journal of Political Economy, forthcoming.

Mahdavi, Mahnaz and Nicholas J. Horton (2014), Financial Knowledge among Educated Women: Room for Improvement, Journal of Consumer Affairs, 48, 403-417.

Mallows, C.L. (1973), Some Comments on Cp, Technometrics, 15, 661-676.

McGraw Hill Financial Global FinLit Survey data (2015); https://www.finlit.mhfi.com.

OECD (2013), PISA 2012 Results: What Students Know and Can Do, Student Performance in Mathematics, Reading and Science (Volume I), Paris.

Prince, Melvin (1993), Women, Men, and Money Styles, Journal of Economic Psychology, 14, 175-182. 
Tibshirani, R. (1996), Regression Shrinkage and Selection via the LASSO, Journal of the Royal Statistical Society Series B, 58, 267-288.

World Economic Forum (2013), Global Gender Gap Report 2013, Geneva, Switzerland.

Van Rooij, Maarten, Annamaria Lusardi and Rob Alessie (2011), Financial Literacy and Stock Market Participation, Journal of Financial Economics, 101, 449-472.

Van Rooij, Maarten C.J., Annamaria Lusardi and Rob J.M. Alessie (2012), Financial Literacy, Retirement Planning and Household Wealth, Economic Journal, 122, 449-478.

$\mathrm{Xu}$, Lisa and Bilal Zia (2012), Financial Literacy around the World, An Overview of the Evidence with Practical Suggestions for the Way Forward, World Bank Policy Research Working Paper 6107.

Youngsamart, Daungdauwn, Greg Fisher and Charmine E.J. Härtel (2010), Diversity Management in Thailand, in: Jawad Syed and Mustafa F. Özbilgin (eds.), Managing Cultural Diversity in Asia, Cheltenham: Edward Elgar, 416-432. 
Table 1: Descriptive Statistics, Socio-Demographic Variables, Broken Down by Gender

\begin{tabular}{lcccccc}
\hline & \multicolumn{2}{c}{ women } & \multicolumn{2}{c}{ men } & t-test \\
& acronym & mean & s.d. & mean & s.d. & p-value \\
\hline Age (in years) & AGE & 34.36 & $(9.22)$ & 34.78 & $(9.74)$ & 0.31 \\
Education $^{1}$ & EDU & 3.44 & $(1.00)$ & 3.50 & $(0.89)$ & 0.25 \\
Income (in Baht) & Y & 25935 & $(1332)$ & 27591 & $(1191)$ & 0.18 \\
Log of income & lnY & 3.10 & $(0.49)$ & 3.17 & $(0.49)$ & 0.04 \\
Married (yes=1, others=0) & MAR & 0.46 & $(0.50)$ & 0.47 & $(0.50)$ & 0.44 \\
Number of children in HH & CHILD & 0.89 & $(1.07)$ & 0.77 & $(1.00)$ & 0.10 \\
Number of adults in HH & ADULT & 3.03 & $(1.68)$ & 3.91 & $(1.50)$ & 0.20 \\
Numeracy & NUM & 3.55 & $(0.87)$ & 3.57 & $(0.89)$ & 0.42 \\
Risk aversion & RISK & 0.48 & $(0.23)$ & 0.43 & $(0.22)$ & 0.01 \\
Low assets & ASS_l & 0.54 & $(0.50)$ & 0.47 & $(0.50)$ & 0.07 \\
Medium assets & ASS_m & 0.20 & $(0.03)$ & 0.23 & $(0.03)$ & 0.15 \\
High assets & ASS_h & 0.09 & $(0.29)$ & 0.09 & $(0.28)$ & 0.45 \\
Obs. & & \multicolumn{2}{c}{255} & & 275 & \\
\hline
\end{tabular}

Notes: ${ }^{1}$ Education in categories 0 meaning no education, 1 primary school, 2 secondary school, 3 vocational training, 4 bachelor, 5 master, $6 \mathrm{PhD} ;{ }^{2}$ Numeracy is a score between 0 and 4 (definition of items is described in Appendix Table A1). 19\% of the respondents did not answer the question about their amounts of assets. 


\section{Table 2: Descriptive Statistics of Financial Literacy Variables, Broken Down by Gender}

The financial literacy questions are repeated below. The first three questions are multiple choice and responses "I don't know" and "I refuse to answer" are available in addition to the listed options.

\section{Interest rate:}

If you borrow 10000 Baht, at an interest rate of 2\% a month, after 3 months how much do you

2. Inflation: owe? a) Less than 10200 Baht $\quad$ b) More than 10200 Baht c) Exactly 10200 Baht

If you have 10000 Baht in an account, the interest rate on the account is $1 \%$ per year, and the price of goods and services rises by $2 \%$ per year, after one year can you buy:

3. Diversification:
a) Less than today
b) More than today
c) Exactly the same as today

Buying a single company's stock is safer than buying a stock mutual fund.

\section{Borrowing choice:}

a) True b) False

Suppose you need to borrow 50000 Baht. Two people offer you a loan, the first loan you have to pay back 60000 Baht in one month, with the second loan you have to pay back 50000 Baht plus $15 \%$ in one month. Which loan is the better option?

a) The first loan b) The second loan

\section{Institutional knowledge:}

Name foreign banks. Open answers

\begin{tabular}{lcccccc}
\hline & & \multicolumn{2}{c}{ women } & \multicolumn{2}{c}{ men } & t-test \\
& acronym & mean & s.d. & mean & s.d. & p-value \\
\hline Question 1 & FL1 & 0.78 & $(0.41)$ & 0.80 & $(0.40)$ & 0.33 \\
Question 2 & FL2 & 0.63 & $(0.48)$ & 0.62 & $(0.49)$ & 0.55 \\
Question 3 & FL3 & 0.25 & $(0.43)$ & 0.23 & $(0.42)$ & 0.28 \\
Question 4 & FL4 & 0.72 & $(0.45)$ & 0.75 & $(0.44)$ & 0.27 \\
Question 5 & FBname & 2.19 & $(0.07)$ & 2.27 & $(0.07)$ & 0.21 \\
$\begin{array}{l}\text { Financial Literacy } \\
\quad \text { Score out of 3 }\end{array}$ & FL3score & 1.66 & $(0.05)$ & 1.65 & $(0.05)$ & 0.44 \\
$\quad$ Financial Literacy & FL_sum & 2.39 & $(0.07)$ & 2.38 & $(0.07)$ & 0.44 \\
$\quad$ Score out of 4 & & & & & & \\
$\quad \begin{array}{l}\text { Financial Literacy } \\
\quad \text { Combination score }\end{array}$ & FLnew & 2.23 & $(1.05)$ & 2.20 & $(0.97)$ & 0.35 \\
$\begin{array}{l}\text { Financial Literacy } \\
\quad \text { Factor score }\end{array}$ & FL & 0.01 & $(1.02)$ & -0.01 & $(0.99)$ & 0.41 \\
$\begin{array}{l}\text { Number of times } \\
\text { said “I don't know” }\end{array}$ & FL_DK_sum & 0.71 & $(0.05)$ & 0.73 & $(0.05)$ & 0.40 \\
\hline
\end{tabular}

Note: We generate the "combination score" by awarding one point for each of the three Lusardi and Mitchell questions answered correctly and 0.25 points for each foreign bank named, hence naming four foreign banks (the maximum) is weighted the same as getting one question right. 
Table 3: Explaining the Degree of Financial Literacy

(1)

(2)

(3)

(4)

(5)

Financial Financial Financial Financial Financial

Literacy Literacy Literacy Literacy Literacy

\begin{tabular}{lccccc} 
& all & all & women & men & all \\
\hline Female & 0.0583 & 0.1180 & & & $0.1360^{*}$ \\
& $(0.72)$ & $(1.52)$ & & & $(1.67)$ \\
Age & -0.0237 & -0.0251 & 0.0027 & -0.0357 & -0.0010 \\
& $(-0.65)$ & $(-0.76)$ & $(0.05)$ & $(-0.92)$ & $(-0.03)$ \\
Age sq. & 0.0318 & 0.1190 & -0.403 & 0.3870 & -0.0971 \\
& $(0.06)$ & $(0.26)$ & $(-0.51)$ & $(0.74)$ & $(-0.20)$ \\
Log of & $0.663^{* * *}$ & $0.537^{* * *}$ & $0.653^{* * *}$ & $0.391^{* *}$ & $0.412^{* * *}$ \\
income & $(5.60)$ & $(4.80)$ & $(5.32)$ & $(2.23)$ & $(3.38)$ \\
Higher & $0.334^{* * *}$ & $0.222^{* *}$ & $0.338^{* *}$ & 0.0971 & 0.145 \\
education & $(3.51)$ & $(2.42)$ & $(2.50)$ & $(0.79)$ & $(1.48)$ \\
Risk aversion & & $-1.481^{* * *}$ & $-1.204^{* * *}$ & $1.699^{* * *}$ & $-1.408^{* *}$ \\
& & $(-7.91)$ & $(-4.80)$ & $(-5.88)$ & $(-6.86)$ \\
Mother's & & & & & $0.0843^{* *}$ \\
education & & & & & $(2.43)$ \\
Constant & $-1.552 * *$ & -0.496 & -1.248 & 0.160 & -0.820 \\
& $(-2.07)$ & $(-0.71)$ & $(-1.15)$ & $(0.18)$ & $(-1.12)$ \\
\hline Obs. & 530 & 530 & 255 & 275 & 479
\end{tabular}

Notes: The table shows results for OLS regression analysis with financial literacy as the outcome variable measured by FL_DK_sum (see Table 2). T-statistics are in parentheses. ${ }^{* * *}, * *$ and $*$ denote significance at the $1 \%, 5 \%$ and $10 \%$ levels, respectively. 
Table 4: Financial Literacy and Gender in the U.S.

(1)

Financial

Literacy

All
(2)

Financial

Literacy

Top 50\% of income

distribution.
(3)

Financial

Literacy

Top 30\% of income

distribution.
(4)

Financial

Literacy

Top 50\% of income
(5)

Financial

Literacy

Top 30\% of income

\begin{tabular}{lccccc} 
& & Age $<=60$ & Age $<=60$ & Age $<=50$ & Age $<=50$ \\
\hline Female & $-0.223^{* * *}$ & $-0.286^{* * *}$ & $-0.279^{* * *}$ & $-0.338^{* * *}$ & $-0.330^{* * *}$ \\
Age & $(-7.979)$ & $(-7.323)$ & $(-6.355)$ & $(-6.388)$ & $(-5.001)$ \\
& $0.019 * *$ & $0.051^{* * *}$ & $0.059 * *$ & 0.042 & 0.068 \\
Age squared & $(2.344)$ & $(2.801)$ & $(2.558)$ & $(1.156)$ & $(1.427)$ \\
& -0.000 & $-0.000^{* *}$ & $-0.001^{* *}$ & -0.000 & -0.001 \\
College education & $(-0.608)$ & $(-2.171)$ & $(-2.095)$ & $(-0.682)$ & $(-1.076)$ \\
Dummy & $0.369 * * *$ & $0.343^{* * *}$ & $0.371 * * *$ & $0.414^{* * *}$ & $0.469 * * *$ \\
Log of income & $(12.125)$ & $(7.984)$ & $(7.198)$ & $(6.982)$ & $(5.989)$ \\
& $0.231^{* * *}$ & $0.231^{* * *}$ & $0.150^{* * *}$ & $0.267 * * *$ & $0.226^{* * *}$ \\
Risk aversion & $(13.649)$ & $(5.885)$ & $(3.358)$ & $(4.756)$ & $(3.263)$ \\
& $0.079 * *$ & $0.089 *$ & 0.066 & -0.021 & -0.083 \\
Constant & $(2.293)$ & $(1.683)$ & $(1.049)$ & $(-0.295)$ & $(-0.902)$ \\
& $-1.271 * * *$ & $-1.852^{* * *}$ & -1.061 & $-2.138 * *$ & $-2.136^{*}$ \\
$\mathrm{R}^{2}$ & $(-5.654)$ & $(-3.459)$ & $(-1.526)$ & $(-2.507)$ & $(-1.892)$ \\
Obs. & 0.24 & 0.16 & 0.16 & 0.17 & 0.18 \\
\hline
\end{tabular}

Notes: All respondents are responsible for the household's financial decisions. Financial literacy is measured by the three standard Lusardi-Mitchell items (FL3score). In columns (2) and (4) respondents need to have annual income of $\$ 55,000$ or more as a condition for inclusion in the sample, while in columns (3) and (5) the lower income limit is $\$ 87,500$. The table reports OLS estimated coefficients and t-statistics in parentheses. ***, ** and * denote significance at the $1 \%$, 5\% and $10 \%$ levels, respectively. 
Table 5: Financial Literacy and Gender in Urban and Rural Thailand

\begin{tabular}{|c|c|c|c|c|}
\hline & $\begin{array}{c}\text { (1) } \\
\text { Financial } \\
\text { Literacy } \\
\text { Bangkok } \\
\text { All }\end{array}$ & $\begin{array}{c}(2) \\
\text { Financial } \\
\text { Literacy } \\
\text { Buri Ram } \\
\text { All }\end{array}$ & $\begin{array}{c}\text { (3) } \\
\text { Financial } \\
\text { Literacy } \\
\text { Buri Ram } \\
\text { Age }<=60\end{array}$ & $\begin{array}{c}\text { (4) } \\
\text { Financial } \\
\text { Literacy } \\
\text { Buri Ram } \\
\text { Age }<=50\end{array}$ \\
\hline Female & $\begin{array}{c}0.118 \\
(0.077)\end{array}$ & $\begin{array}{c}-0.049 \\
(0.073)\end{array}$ & $\begin{array}{l}-0.038 \\
(0.094)\end{array}$ & $\begin{array}{c}0.100 \\
(0.128)\end{array}$ \\
\hline Age & $\begin{array}{l}-0.0251 \\
(0.0311)\end{array}$ & $\begin{array}{c}0.022 \\
(0.019)\end{array}$ & $\begin{array}{l}-0.003 \\
(0.040)\end{array}$ & $\begin{array}{c}0.073 \\
(0.072)\end{array}$ \\
\hline Age squared & $\begin{array}{c}0.000 \\
(0.000)\end{array}$ & $\begin{array}{c}-0.000 \\
(0.000)\end{array}$ & $\begin{array}{l}-0.000 \\
(0.000)\end{array}$ & $\begin{array}{l}-0.001 \\
(0.001)\end{array}$ \\
\hline Log of income & $\begin{array}{c}0.537 * * * \\
(0.097)\end{array}$ & & & \\
\hline Household assets & & $\begin{array}{c}0.000 \\
(0.000)\end{array}$ & $\begin{array}{l}-0.000 \\
(0.000)\end{array}$ & $\begin{array}{l}-0.000 \\
(0.000)\end{array}$ \\
\hline Higher education & $\begin{array}{l}0.222 * * \\
(0.0856)\end{array}$ & & & \\
\hline Years of education & & $\begin{array}{c}0.035 * * \\
(0.014)\end{array}$ & $\begin{array}{c}0.027^{*} \\
(0.016)\end{array}$ & $\begin{array}{c}0.032 \\
(0.019)\end{array}$ \\
\hline Risk aversion & $\begin{array}{c}-1.481 * * * \\
(0.175)\end{array}$ & $\begin{array}{c}-0.293 * * \\
(0.123)\end{array}$ & $\begin{array}{c}-0.321^{* *} \\
(0.156)\end{array}$ & $\begin{array}{l}-0.333 \\
(0.208)\end{array}$ \\
\hline Constant & $\begin{array}{l}-0.496 \\
(0.696)\end{array}$ & $\begin{array}{l}1.195^{* *} \\
(0.564)\end{array}$ & $\begin{array}{l}1.891^{* *} \\
(0.920)\end{array}$ & $\begin{array}{c}0.489 \\
(1.374)\end{array}$ \\
\hline $\mathrm{R}^{2}$ & 0.23 & 0.05 & 0.02 & 0.04 \\
\hline Obs. & 530 & 697 & 448 & 269 \\
\hline
\end{tabular}

Notes: The table reports OLS estimated coefficients and robust standard errors in parentheses. ${ }^{* * *}$, ** and * denote significance at the $1 \%, 5 \%$ and $10 \%$ levels, respectively. Financial literacy is measured by three financial literacy questions. We use the standard questions in the version as used in Cole et al. (2011), because this version is more suitable for poorer respondents in a development country context. Column (1) reports results based on the Bangkok sample, and is identical to column (2) in Table 3. Columns (2)-(4) report results based on the rural sample. We substitute income by household assets as the income measure sometimes has negative values. Regarding education, there would be hardly any "higher education" (i.e. minimum of a bachelor degree) in the rural area, thus we use years of education (the median here is about five years). 
Table 6: Financial Literacy Gender Gap and Gender Equality

\begin{tabular}{|c|c|c|c|c|c|c|c|}
\hline & $\begin{array}{l}\text { Expec. } \\
\text { sign }\end{array}$ & $\begin{array}{l}\text { (1) } \\
\text { Gender } \\
\text { Gap } \\
\text { All }\end{array}$ & $\begin{array}{c}(2) \\
\text { Gender } \\
\text { Gap } \\
\text { Excl. } \\
\text { Arabic } \\
\text { Countries }\end{array}$ & $\begin{array}{l}\text { (3) } \\
\text { Gender } \\
\text { Gap } \\
\text { All }\end{array}$ & $\begin{array}{c}(4) \\
\text { Gender } \\
\text { Gap } \\
\text { Excl. } \\
\text { Arabic } \\
\text { Countries }\end{array}$ & $\begin{array}{c}\text { (5) } \\
\text { Gender } \\
\text { Gap } \\
\text { All }\end{array}$ & $\begin{array}{c}(6) \\
\text { Gender } \\
\text { Gap } \\
\text { Excl. } \\
\text { Arabic } \\
\text { Countries }\end{array}$ \\
\hline $\begin{array}{l}\text { Gender equality } \\
\text { index }\end{array}$ & - & $\begin{array}{c}1.073 \\
(7.975)\end{array}$ & $\begin{array}{l}-0.858 \\
(9.250)\end{array}$ & & & & \\
\hline $\begin{array}{l}\text { Hofstede } \\
\text { Masculinity Index }\end{array}$ & + & & & $\begin{array}{c}-0.063 * * \\
(0.028)\end{array}$ & $\begin{array}{c}-0.064 * * \\
(0.028)\end{array}$ & & \\
\hline $\begin{array}{l}\text { Fem. legisla., manag. } \\
\text { sen. offic. (\% total) }\end{array}$ & - & & & & & $\begin{array}{l}-0.063 \\
(0.041)\end{array}$ & $\begin{array}{c}-0.119 * * \\
(0.048)\end{array}$ \\
\hline Log GDP per capita & & $\begin{array}{c}0.577 \\
(0.422)\end{array}$ & $\begin{array}{l}0.809 * \\
(0.461)\end{array}$ & $\begin{array}{c}0.576 \\
(0.508)\end{array}$ & $\begin{array}{c}0.759 \\
(0.511)\end{array}$ & $\begin{array}{c}0.764 \\
(0.506)\end{array}$ & $\begin{array}{l}1.241^{* *} \\
(0.532)\end{array}$ \\
\hline Constant & & $\begin{array}{c}0.233 \\
(5.654)\end{array}$ & $\begin{array}{l}-0.558 \\
(6.180)\end{array}$ & $\begin{array}{c}4.197 \\
(5.144)\end{array}$ & $\begin{array}{l}2.597 \\
(5.167)\end{array}$ & $\begin{array}{c}0.943 \\
(4.918)\end{array}$ & $\begin{array}{c}-1.732 \\
(5.051)\end{array}$ \\
\hline$\overline{\mathrm{R}^{2}}$ & & 0.02 & 0.03 & 0.07 & 0.09 & 0.04 & 0.10 \\
\hline Obs. & & 117 & 106 & 84 & 79 & 101 & 92 \\
\hline
\end{tabular}

Notes: The table reports OLS regression results with standard errors in brackets. The dependent variable is the financial literacy gender gap, which is calculated as the proportion of financially literate men minus the proportion of financially literate women. The explanatory variables are different measures of gender equality. Column (1) shows the relationship between the financial literacy gender gap index as published by the World Economic Forum. Column (3) shows the relationship with the Hofstede Masculinity Index and Column (5) we show the relationship between the financial literacy gender gap and the proportion of female legislators, managers and senior officials. We control for log GDP per capita in all regressions. Even numbered columns show the same regressions, but excluding all countries that are member of the Arab League. ${ }^{* * *}$, ${ }^{* *}$ and ${ }^{*}$ denote significance at the $1 \%, 5 \%$ and $10 \%$ levels, respectively. 
Table 7: Financial Literacy Gender Gap and Finance Specific Equity

\begin{tabular}{|c|c|c|c|c|c|c|c|}
\hline & $\begin{array}{l}\text { Expec. } \\
\text { sign }\end{array}$ & $\begin{array}{l}(1) \\
\text { Gender } \\
\text { gap } \\
\text { All } \\
\end{array}$ & $\begin{array}{c}\text { (2) } \\
\text { Gender } \\
\text { gap } \\
\text { All } \\
\end{array}$ & $\begin{array}{c}\text { (3) } \\
\text { Gender } \\
\text { gap } \\
\text { All } \\
\end{array}$ & $\begin{array}{c}(4) \\
\text { Gender } \\
\text { gap } \\
\text { All } \\
\end{array}$ & $\begin{array}{c}\text { (5) } \\
\text { Gender } \\
\text { gap } \\
\text { All } \\
\end{array}$ & $\begin{array}{c}(6) \\
\text { Gender } \\
\text { gap } \\
\text { All } \\
\end{array}$ \\
\hline Girls PISA math score & - & $\begin{array}{c}0.021 \\
(0.019)\end{array}$ & & & & & \\
\hline $\begin{array}{l}\text { Gap in secondary } \\
\text { school enrollment }\end{array}$ & + & & $\begin{array}{l}0.147^{*} \\
(0.07)\end{array}$ & & & & \\
\hline $\begin{array}{l}\text { Graduate in business, } \\
\text { law, soc. sci. (\%total) }\end{array}$ & - & & & $\begin{array}{l}-0.018 \\
(0.048)\end{array}$ & & & \\
\hline $\begin{array}{l}\text { Household fin. dec. by } \\
\text { women (\%) }\end{array}$ & - & & & & $\begin{array}{l}-0.175 \\
(0.358)\end{array}$ & & \\
\hline $\begin{array}{l}\text { Female labor force } \\
\text { participation }\end{array}$ & - & & & & & $\begin{array}{c}0.012 \\
(0.027)\end{array}$ & \\
\hline Wage equality & - & & & & & & $\begin{array}{c}0.003 \\
(0.012)\end{array}$ \\
\hline Log GDP per capita & & $\begin{array}{c}0.589 \\
(1.646)\end{array}$ & $\begin{array}{c}0.645 \\
(0.407)\end{array}$ & $\begin{array}{c}0.574 \\
(0.482)\end{array}$ & $\begin{array}{c}2.330 \\
(1.839)\end{array}$ & $\begin{array}{c}0.524 \\
(0.365)\end{array}$ & $\begin{array}{c}0.588 \\
(0.402)\end{array}$ \\
\hline Constant & & $\begin{array}{c}-8.665 \\
(12.666)\end{array}$ & $\begin{array}{c}0.490 \\
(3.836)\end{array}$ & $\begin{array}{l}2.007 \\
(4.370)\end{array}$ & $\begin{array}{c}-7.148 \\
(28.796)\end{array}$ & $\begin{array}{c}0.818 \\
(4.101)\end{array}$ & $\begin{array}{c}0.700 \\
(3.860)\end{array}$ \\
\hline $\mathrm{R}^{2}$ & & 0.06 & 0.05 & 0.01 & 0.17 & 0.02 & 0.02 \\
\hline Obs. & & 58 & 102 & 101 & 15 & 136 & 115 \\
\hline $\begin{array}{l}\text { Notes: The table reports O } \\
\text { gap, which is calculated as } \\
\text { women. Column (1) report } \\
\text { OECD (2012). Column (2) } \\
\text { country. Column (3) shows } \\
\text { graduates in business, law } \\
\text { percentage of households t } \\
\text { was collected and publishe } \\
\text { force participation as a pro } \\
\text { wage equality and the fina } \\
\text { from the World Bank webs } \\
\text { significance at the } 1 \%, 5 \%\end{array}$ & $\begin{array}{l}\text { LS regres } \\
\text { the propo } \\
\text { s the relat } \\
\text { reports th } \\
\text { the relat } \\
\text { and social } \\
\text { hat report } \\
\text { d by Mas } \\
\text { portion of } \\
\text { cial liter } \\
\text { ite. We c }\end{array}$ & $\begin{array}{l}\text { ion results } \\
\text { rtion of fina } \\
\text { onship with } \\
\text { e gap in the } \\
\text { onship betw } \\
\text { sciences the } \\
\text { that women } \\
\text { er Card in } 2 \\
\text { all women } \\
\text { cy gender g } \\
\text { ntrol for log }\end{array}$ & $\begin{array}{l}\text { h standarc } \\
\text { ially litera } \\
\text { jerage ma } \\
\text { oportion } \\
\text { n the fina } \\
\text { are wome } \\
\text { ake finan } \\
\text { 2. Colum } \\
\text { ove the ag } \\
\text { Unless s } \\
\text { iDP per c }\end{array}$ & $\begin{array}{l}\text { rors in } b \\
\text { men mir } \\
\text { score by } \\
\text { oys and } \\
\text { al literac } \\
\text { Column } \\
\text { decisio } \\
\text { ) shows } \\
\text { f } 15 \text {. Co } \\
\text { d otherv } \\
\text { ta in all }\end{array}$ & $\begin{array}{l}\text { kets. The } \\
\text { he props } \\
\text { s in the } \\
\text { ls enrolle } \\
\text { ender ga } \\
\text { how reg } \\
\text { r } 15 \text { Asi } \\
\text { ression I } \\
\text { in (6) sh } \\
\text { the dat } \\
\text { essions. }\end{array}$ & $\begin{array}{l}\text { pendent } \mathrm{v} \\
\text { on of fina } \\
\text { A test as } 1 \\
\text { a seconda } \\
\text { d the pro } \\
\text { sions resu } \\
\text { cific cour } \\
\text { lts with f } \\
\text { the relati } \\
\text { this table } \\
*, * * \text { and }\end{array}$ & $\begin{array}{l}\text { able is gende } \\
\text { ally literate } \\
\text { lished by the } \\
\text { school in a } \\
\text { tion on } \\
\text { between the } \\
\text { es, the data } \\
\text { le labor } \\
\text { hip between } \\
\text { s collected } \\
\text { lenote }\end{array}$ \\
\hline
\end{tabular}


Figure 1: Financial Literacy Gender Gap across Countries

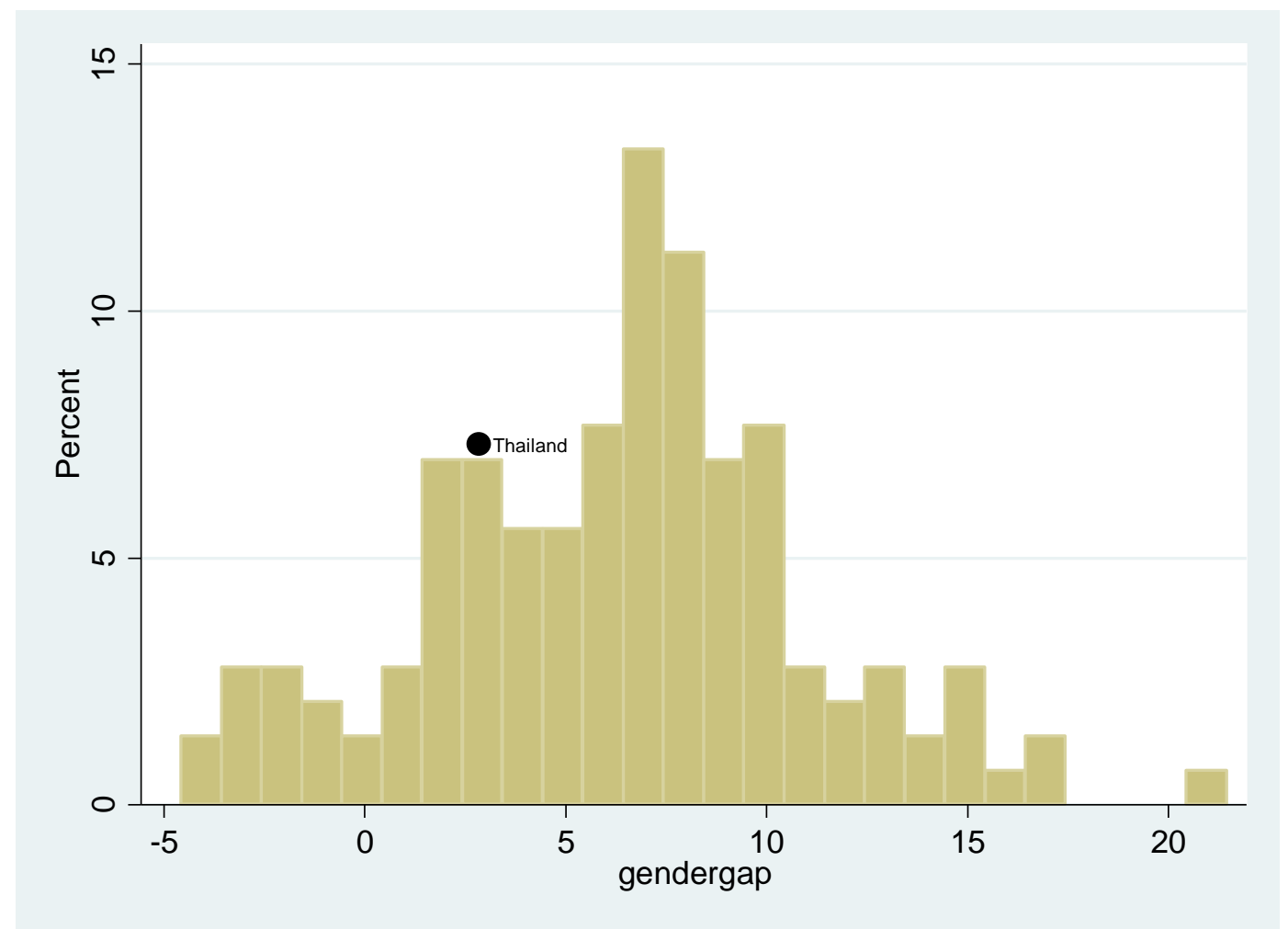

Notes: The graph shows the financial literacy gender gap across countries. The gender gap is calculated based on the S\&P Global Financial Literacy data, which codes a respondent as financially literate as if she or he can answer three out of four financial literacy questions correctly. The data give the proportion of men and women that are financially literate. We calculate the gap as proportion of financially literate men minus proportion of financially literate women. In Thailand the proportion of men that are financially literate is $3 \%$ point higher than the proportion of women that are financially literate. 
Figure 2: Relative Financial Literacy Gender Gap and Gender Equality Index

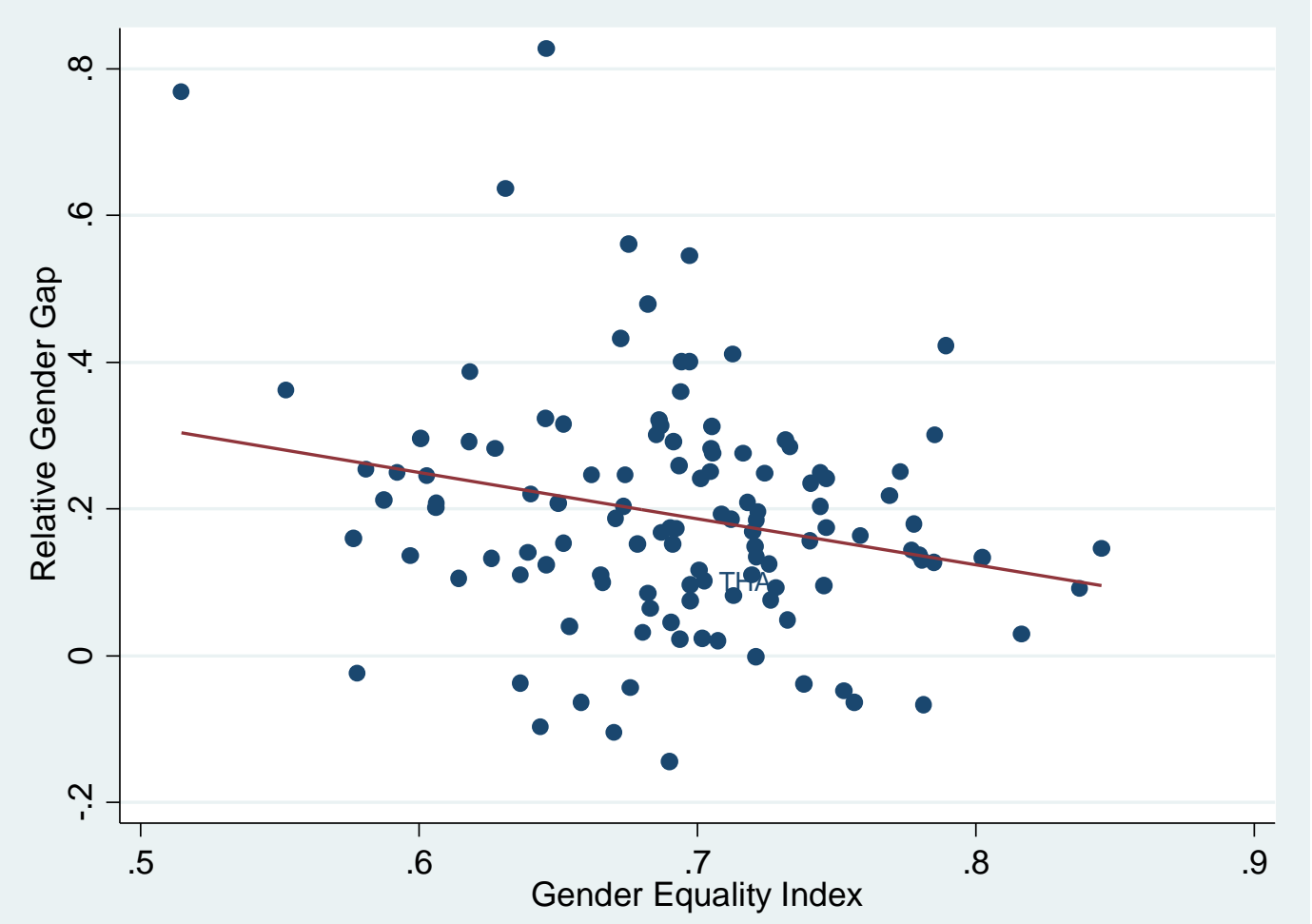

Notes: The graph plots the relationship between the relative financial literacy gender gap, calculated as the proportion of financially literate men minus the proportion of financially literate women divided by proportion of all financially literate people in that country, and the gender equality index as published by the World Economic Forum in 2013. The ordinate is Relative Financial Literacy Gender Gap. This relationship is statistically significant at 5\%. 
Figure 3: Financial Literacy Gender Gap and Difference in Proportion of Each Gender Enrolled in Secondary School.

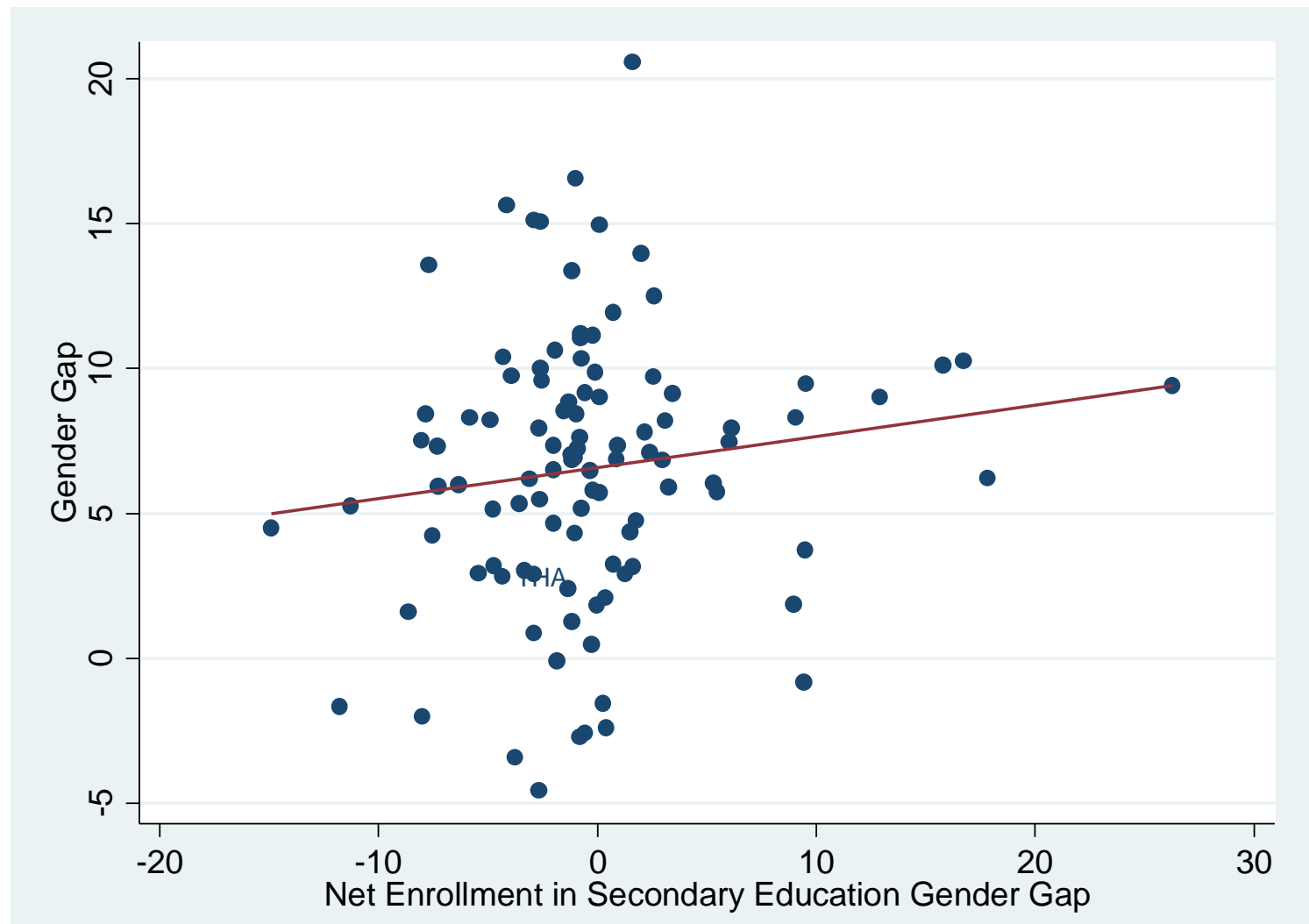

Notes: The graph plots the relationship between the financial literacy gender gap, calculated as the proportion of financially literate men minus the proportion of financially literate women, and gender gap enrollment in secondary school, calculated as the proportion of each gender enrolled in secondary school. The ordinate is Financial Literacy Gender Gap. This relationship is not statistically significant. 


\section{APPENDIX}

to

"Financial literacy: Thai middle class women do not lag behind"

(not intended for being printing) 


\section{Table A1: Numeracy and Risk Questions}

\section{Numeracy Questions:}

1. What is $35+82$ ?

2. If you have four friends and would like to give each of your friends four sweets, how many sweets do you need?

3. What is $10 \%$ of 400 ?

4. Suppose you want to buy a bag of rice that costs 370 Baht. You only have one 1000 Baht note. How much change will you get?

\section{Risk Question:}

Are you a person who is prepared to take risk, or do you avoid taking risk?

Please choose a number on a scale from 0 (meaning unwilling to take risk) to 10 (meaning fully prepared to take risk)

\begin{tabular}{lccccc}
\hline & \multicolumn{2}{c}{ female } & \multicolumn{2}{c}{ male } & t-test \\
& mean & sd & mean & sd & p-value \\
\hline Risk aversion & 0.478 & $(0.23)$ & 0.434 & $(0.22)$ & 0.013 \\
Numeracy & 3.553 & $(0.87)$ & 3.567 & $(0.89)$ & 0.426 \\
\hline
\end{tabular}

Table A2: Financial Literacy and Gender: Sample Splits

\begin{tabular}{|c|c|c|c|c|c|c|}
\hline & $\begin{array}{c}\text { (1) } \\
\text { Financial } \\
\text { Literacy } \\
\text { No Higher } \\
\text { education }\end{array}$ & $\begin{array}{c}\text { (2) } \\
\text { Financial } \\
\text { Literacy } \\
\text { Higher } \\
\text { education }\end{array}$ & $\begin{array}{c}\text { (3) } \\
\text { Financial } \\
\text { Literacy } \\
\text { HH } \\
\text { income } \\
<=50000\end{array}$ & $\begin{array}{c}\text { (4) } \\
\text { Financial } \\
\text { Literacy } \\
\text { HH } \\
\text { income } \\
>50000\end{array}$ & $\begin{array}{c}(5) \\
\text { Financial } \\
\text { Literacy } \\
\text { Age }<=33\end{array}$ & $\begin{array}{c}(6) \\
\text { Financial } \\
\text { Literacy } \\
\text { Age }>33\end{array}$ \\
\hline Female & $\begin{array}{c}-0.038 \\
{[0.166]}\end{array}$ & $\begin{array}{c}0.214^{* *} \\
{[0.083]}\end{array}$ & $\begin{array}{c}0.085 \\
{[0.097]}\end{array}$ & $\begin{array}{c}0.153 \\
{[0.132]}\end{array}$ & $\begin{array}{c}0.201^{*} \\
{[0.104]}\end{array}$ & $\begin{array}{c}-0.012 \\
{[0.121]}\end{array}$ \\
\hline $\begin{array}{l}\text { Age in } \\
\text { years }\end{array}$ & $\begin{array}{c}-0.008 \\
{[0.065]}\end{array}$ & $\begin{array}{c}-0.028 \\
{[0.033]}\end{array}$ & $\begin{array}{c}0.016 \\
{[0.053]}\end{array}$ & $\begin{array}{c}-0.065 \\
{[0.049]}\end{array}$ & $\begin{array}{l}-0.154 \\
{[0.258]}\end{array}$ & $\begin{array}{c}-0.000 \\
{[0.106]}\end{array}$ \\
\hline $\begin{array}{l}\text { Age } \\
\text { squared }\end{array}$ & $\begin{array}{c}-0.000 \\
{[0.001]}\end{array}$ & $\begin{array}{c}0.000 \\
{[0.000]}\end{array}$ & $\begin{array}{c}-0.000 \\
{[0.001]}\end{array}$ & $\begin{array}{c}0.001 \\
{[0.001]}\end{array}$ & $\begin{array}{c}0.003 \\
{[0.005]}\end{array}$ & $\begin{array}{c}-0.000 \\
{[0.001]}\end{array}$ \\
\hline Log income & $\begin{array}{c}0.665 * * * \\
{[0.198]}\end{array}$ & $\begin{array}{c}0.407 * * * \\
{[0.122]}\end{array}$ & $\begin{array}{c}0.752^{* * *} \\
{[0.186]}\end{array}$ & $\begin{array}{c}0.381 * * \\
{[0.185]}\end{array}$ & $\begin{array}{l}0.483^{*} \\
{[0.283]}\end{array}$ & $\begin{array}{c}0.502 * * * \\
{[0.122]}\end{array}$ \\
\hline $\begin{array}{l}\text { Higher } \\
\text { education }\end{array}$ & & & $\begin{array}{c}0.114 \\
{[0.099]}\end{array}$ & $\begin{array}{l}0.388^{*} \\
{[0.200]}\end{array}$ & $\begin{array}{c}0.106 \\
{[0.135]}\end{array}$ & $\begin{array}{c}0.402^{* * *} \\
{[0.139]}\end{array}$ \\
\hline $\begin{array}{l}\text { Risk } \\
\text { aversion }\end{array}$ & $\begin{array}{c}-1.442 * * * \\
{[0.389]}\end{array}$ & $\begin{array}{c}-1.444 * * * \\
{[0.194]}\end{array}$ & $\begin{array}{c}-1.475 * * * \\
{[0.241]}\end{array}$ & $\begin{array}{c}-1.427 * * * \\
{[0.312]}\end{array}$ & $\begin{array}{c}-1.496 * * * \\
{[0.269]}\end{array}$ & $\begin{array}{c}-1.416 * * * \\
{[0.292]}\end{array}$ \\
\hline Constant & $\begin{array}{c}-0.890 \\
{[1.354]}\end{array}$ & $\begin{array}{c}-0.050 \\
{[0.677]}\end{array}$ & $\begin{array}{c}-1.722 * \\
{[1.037]}\end{array}$ & $\begin{array}{c}0.520 \\
{[0.988]}\end{array}$ & $\begin{array}{c}1.377 \\
{[3.469]}\end{array}$ & $\begin{array}{c}-1.078 \\
{[2.381]}\end{array}$ \\
\hline $\mathrm{R}^{2}$ & 0.20 & 0.20 & 0.21 & 0.20 & 0.18 & 0.28 \\
\hline Obs. & 175 & 355 & 327 & 203 & 265 & 250 \\
\hline
\end{tabular}

Notes: The table reports OLS regression results with standard errors in brackets. The dependent variable is the financial literacy factor score FL_DK_sum. We split sample, whether the respondent has a higher educational degree in columns (1) and (2), at the median household income of 50000 baht p.m. in columns (3) and (4), and at the median age of 33 in columns (5) and (6). ${ }^{* * *},{ }^{* *}$ and * denote significance at the $1 \%, 5 \%$ and $10 \%$ levels, respectively. 
Table A3: Financial Literacy and Gender in the Netherlands

\begin{tabular}{|c|c|c|c|c|c|}
\hline & $\begin{array}{c}(1) \\
\text { Financial } \\
\text { Literacy } \\
\text { All }\end{array}$ & $\begin{array}{c}(2) \\
\text { Financial } \\
\text { Literacy } \\
\text { Top 50\% of } \\
\text { income } \\
\text { distribution. } \\
\text { Age }<=60\end{array}$ & $\begin{array}{c}(3) \\
\text { Financial } \\
\text { Literacy } \\
\text { Top 30\% of } \\
\text { income } \\
\text { distribution. } \\
\text { Age }<=60\end{array}$ & $\begin{array}{c}\text { (4) } \\
\text { Financial } \\
\text { Literacy } \\
\text { Top 50\% of } \\
\text { income } \\
\text { distribution. } \\
\text { Age }<=50\end{array}$ & $\begin{array}{c}\text { (5) } \\
\text { Financial } \\
\text { Literacy } \\
\text { Top 30\% of } \\
\text { income } \\
\text { distribution. } \\
\text { Age }<=50\end{array}$ \\
\hline Female & $\begin{array}{c}-0.432 * * * \\
(6.725)\end{array}$ & $\begin{array}{c}-0.603^{* * *} \\
(-4.750)\end{array}$ & $\begin{array}{c}-0.472 * * * \\
(3.151)\end{array}$ & $\begin{array}{c}-0.505^{* * *} \\
(-3.360)\end{array}$ & $\begin{array}{c}-0.437 * * \\
(2.515)\end{array}$ \\
\hline Age & $\begin{array}{c}0.223 * * * \\
(4.279)\end{array}$ & $\begin{array}{c}-0.067 \\
(-1.181)\end{array}$ & $\begin{array}{c}0.043 \\
(0.303)\end{array}$ & $\begin{array}{c}-0.150 \\
(-1.241)\end{array}$ & $\begin{array}{c}0.080 \\
(0.411)\end{array}$ \\
\hline Age squared & $\begin{array}{c}0.003 \\
(0.241)\end{array}$ & $\begin{array}{c}0.614 \\
(0.958)\end{array}$ & $\begin{array}{c}-0.099 \\
(-1.431)\end{array}$ & $\begin{array}{l}1.747 \\
(1.141)\end{array}$ & $\begin{array}{c}-0.181 \\
(-1.239)\end{array}$ \\
\hline $\begin{array}{l}\text { Education more than } \\
\text { high school }\end{array}$ & $\begin{array}{c}-0.005 \\
(-0.047)\end{array}$ & $\begin{array}{l}0.328^{* *} \\
(2.249)\end{array}$ & $\begin{array}{c}0.938 \\
(1.213)\end{array}$ & $\begin{array}{c}0.323 \\
(1.614)\end{array}$ & $\begin{array}{c}2.049 \\
(1.109)\end{array}$ \\
\hline Log of income & $\begin{array}{c}0.481 * * * \\
(7.387)\end{array}$ & $\begin{array}{c}0.221 \\
(0.998)\end{array}$ & $\begin{array}{c}0.196 \\
(1.027)\end{array}$ & $\begin{array}{c}0.356 \\
(1.099)\end{array}$ & $\begin{array}{l}0.526^{*} \\
(1.874)\end{array}$ \\
\hline Risk aversion & $\begin{array}{l}0.032 * \\
(1.673)\end{array}$ & $\begin{array}{c}0.106 \\
(0.994)\end{array}$ & $\begin{array}{c}-0.018 \\
(-0.089)\end{array}$ & $\begin{array}{c}0.164 \\
(1.156)\end{array}$ & $\begin{array}{c}0.075 \\
(0.225)\end{array}$ \\
\hline Constant & $\begin{array}{l}0.780 * * \\
(2.404)\end{array}$ & $\begin{array}{l}1.261 \\
(0.615)\end{array}$ & $\begin{array}{l}4.345^{*} \\
(1.955)\end{array}$ & $\begin{array}{l}1.672 \\
(0.547)\end{array}$ & $\begin{array}{c}4.734 \\
(1.322)\end{array}$ \\
\hline $\mathrm{R}^{2}$ & 0.14 & 0.12 & 0.08 & 0.09 & 0.10 \\
\hline Obs. & 1026 & 294 & 191 & 189 & 123 \\
\hline
\end{tabular}

Notes: All respondents are responsible for the household's financial decisions. Financial literacy is measured by the three standard Lusardi-Mitchell items (FL3score). In columns (2) and (4) respondents need to have monthly income of 2,400 euro or more as a condition for inclusion in the sample, while in columns (3) and (5) the lower income limit is 3,000 euro. The table reports OLS estimated coefficients and t-statistics in parentheses. Age squared is divided by 1,000 here. ***, ** and * denote significance at the $1 \%, 5 \%$ and $10 \%$ levels, respectively.

On data and result: For the Netherlands we rely on the Longitudinal Internet Study for the Social Sciences (LISS), a household survey conducted by CentERdata at Tilburg University. We use a module from the LISS database with financial literacy data for more than 1,800 persons. Similar to the U.S. case, there is a significant gender gap which does not disappear by cutting down the sample in order to make it similar to our Thai sample. 
Table A4: Financial Literacy and Gender in Germany

\begin{tabular}{|c|c|c|c|c|c|}
\hline & $\begin{array}{c}(1) \\
\text { Financial } \\
\text { Literacy } \\
\text { All }\end{array}$ & $\begin{array}{c}(2) \\
\text { Financial } \\
\text { Literacy } \\
\text { Top } 50 \% \text { of } \\
\text { income } \\
\text { distribution. } \\
\text { Age }<=60\end{array}$ & $\begin{array}{c}\text { (3) } \\
\text { Financial } \\
\text { Literacy } \\
\text { Top 30\% of } \\
\text { income } \\
\text { distribution. } \\
\text { Age }<=60\end{array}$ & $\begin{array}{c}(4) \\
\text { Financial } \\
\text { Literacy } \\
\text { Top 50\% of } \\
\text { income } \\
\text { distribution. } \\
\text { Age }<=50\end{array}$ & $\begin{array}{c}\text { (5) } \\
\text { Financial } \\
\text { Literacy } \\
\text { Top 30\% of } \\
\text { income } \\
\text { distribution. } \\
\text { Age }<=50\end{array}$ \\
\hline Female & $\begin{array}{c}-0.176 * * * \\
{[0.026]}\end{array}$ & $\begin{array}{c}-0.172 * * * \\
{[0.043]}\end{array}$ & $\begin{array}{c}-0.181^{* * * *} \\
{[0.054]}\end{array}$ & $\begin{array}{c}-0.141 * * * \\
{[0.052]}\end{array}$ & $\begin{array}{c}-0.092 \\
{[0.068]}\end{array}$ \\
\hline Age & $\begin{array}{c}0.004 \\
{[0.006]}\end{array}$ & $\begin{array}{l}-0.008 \\
{[0.023]}\end{array}$ & $\begin{array}{c}-0.016 \\
{[0.029]}\end{array}$ & $\begin{array}{c}0.042 \\
{[0.048]}\end{array}$ & $\begin{array}{c}0.061 \\
{[0.059]}\end{array}$ \\
\hline $\begin{array}{l}\text { Age } \\
\text { squared }\end{array}$ & $\begin{array}{l}-0.000 \\
{[0.000]}\end{array}$ & $\begin{array}{c}0.000 \\
{[0.000]}\end{array}$ & $\begin{array}{c}0.000 \\
{[0.000]}\end{array}$ & $\begin{array}{c}-0.001 \\
{[0.001]}\end{array}$ & $\begin{array}{c}-0.001 \\
{[0.001]}\end{array}$ \\
\hline $\begin{array}{l}\text { Log of } \\
\text { income }\end{array}$ & $\begin{array}{c}0.189 * * * \\
{[0.022]}\end{array}$ & $\begin{array}{l}0.122^{*} \\
{[0.066]}\end{array}$ & $\begin{array}{l}0.167 * \\
{[0.092]}\end{array}$ & $\begin{array}{l}0.170 * * \\
{[0.082]}\end{array}$ & $\begin{array}{l}0.246 * * \\
{[0.122]}\end{array}$ \\
\hline $\begin{array}{l}\text { Higher } \\
\text { education }\end{array}$ & $\begin{array}{c}0.301 * * * \\
{[0.029]}\end{array}$ & $\begin{array}{c}0.302 * * * \\
{[0.056]}\end{array}$ & $\begin{array}{c}0.314 * * * \\
{[0.073]}\end{array}$ & $\begin{array}{c}0.358 * * * \\
{[0.074]}\end{array}$ & $\begin{array}{c}0.376 * * * \\
{[0.104]}\end{array}$ \\
\hline $\begin{array}{l}\text { Financial } \\
\text { risk aversion }\end{array}$ & $\begin{array}{l}0.010^{* *} \\
{[0.005]}\end{array}$ & $\begin{array}{l}0.021^{* *} \\
{[0.008]}\end{array}$ & $\begin{array}{l}0.022 * * \\
{[0.011]}\end{array}$ & $\begin{array}{c}0.033^{* * *} \\
{[0.010]}\end{array}$ & $\begin{array}{c}0.037 * * * \\
{[0.012]}\end{array}$ \\
\hline Constant & $\begin{array}{c}0.842 * * * \\
{[0.194]}\end{array}$ & $\begin{array}{l}1.564 * * \\
{[0.706]}\end{array}$ & $\begin{array}{c}1.392 \\
{[1.025]}\end{array}$ & $\begin{array}{c}0.120 \\
{[1.125]}\end{array}$ & $\begin{array}{c}-0.891 \\
{[1.661]}\end{array}$ \\
\hline $\mathrm{R}^{2}$ & 0.11 & 0.08 & 0.09 & 0.11 & 0.11 \\
\hline Obs. & 2921 & 885 & 565 & 597 & 355 \\
\hline
\end{tabular}

Notes: The table reports OLS regression results with robust standard errors in brackets. ***, ** and * denote significance at the $1 \%, 5 \%$ and $10 \%$ levels, respectively. The outcome variable is the standard Lusardi-Mitchell financial literacy score out of three, one point is awared for each correct answer (FL3score). Column (1) gives results for the full sample, columns (2) and (4) gives results for the top 50\% of the income distribution. Column (3) and (5) gives results for the top $30 \%$ of the income distribution. We leave out respondents above the age of 60 in columns (2) and (3) and above 50 in columns (4) and (5).

On data and results: For Germany we consider the SAVE dataset, collected by the Munich Centre for the Economics of Aging (MEA). This is a representative panel survey of households in Germany. The survey is designed to study financial decision making, with a particular focus on saving and planning for retirement. We look at 2007 because that wave contains the three basic financial literacy questions and at the same time has more cases $(2,900)$ than the more recent waves. Again, we find that the gender gap in financial literacy is quite robust to variation in sample composition. 


\section{Section A1: Financial behavior of middle class women and men}

This section contains the main information about our results mentioned in Section 7 of the main paper. Our analysis proceeds in two steps. First, descriptive information is shown on six kinds of financial behavior, separated by gender. The information on behavior stems from our survey and the items refer to the specific situation in Thailand, where people often keep a too large proportion of their assets in savings accounts, whereas life insurance policies tentatively provide even lower returns and where the use of credit cards often leads to overindebtedness. We indicate "good" financial behavior in Table A5 and see that women tend to perform slightly better than men with one significant advantage (repaying credit card debt) and one significant disadvantage (knowing credit card interest rate). Thus we can easily conclude on this available evidence that financial behavior of women is equally good to that of men. More information on the specific products is provided in the Appendix Section A2.

As a second step, we analyze the impact of financial literacy and gender on financial behavior in an IV-approach, where financial literacy is instrumented. In line with most literature we expect that financial literacy should have a positive impact, whereas we do not expect a systematic impact from gender on financial behavior for the Thai case. Our procedure is largely agnostic about the selection of determinants and instrumental variables. Accordingly, we employ a least angle regression (LARS) approach (Efron et al., 2004) which is an econometric procedure to select a set of variables from a larger universe of variables that is a compromise between conventional selection procedures producing too small standard errors on the one hand and those that shrink the coefficients towards zero on the other hand.

As elements of the LARS procedure we use available socio-demographic information (see Table 1) and biographical information (see Section A3 and Table A7). The exact procedures are described in the Appendix Section A4, including the outcome of the first-step regression. Here, we just present the coefficients of the instrumented financial literacy variable and of the gender variable while we suppress information on other considered variables. As can be seen from Table A6, for all of the six kinds of financial behavior, financial literacy has a correct sign and five items have a significant impact. By contrast, the gender variable is significant just two times and the signs offset each other, as the impact on the "insurance" behavior is rather undesired whereas behavior regarding the "number of assets" is desired from the viewpoint of financial competence. These results are largely consistent with the evidence from descriptive statistics (see Table A5) and with evidence from non-instrumented regressions, although the latter show less significant results (see Appendix Section A4). 
Furthermore we have determined the reduced form and alternative IV estimates. The results show that the coefficients of financial literacy and female effects on the six kinds of financial behavior deviate only slightly from that in Table A6. Altogether, no sign changes are observed of the FL and FEM effects. The results are also robust, when NoASS is substituted by a dummy (=1 if NoASS $>0$ ) and the probit estimation is carried out (presented in the Appendix Section A4).

Summing up, our results indeed support the notion that financial literacy impacts financial behavior in the expected positive way, and that there is no gender gap in financial behavior: women seem to behave as competent as men do. This underlines our main finding of a missing gender gap in financial literacy among the Thai middle class, which extends to the financial behavior of women. 
Table A5: Descriptive Statistics of Financial Behavior, Broken Down by Gender

\begin{tabular}{|c|c|c|c|c|c|c|}
\hline & \multirow[b]{2}{*}{ acronym } & \multicolumn{2}{|c|}{ women } & \multicolumn{2}{|c|}{ men } & \multirow{2}{*}{$\begin{array}{c}\text { t-test } \\
\text { p-value }\end{array}$} \\
\hline & & mean & s.d. & mean & s.d. & \\
\hline Fixed deposit & DEPO & 0.44 & $(0.50)$ & 0.38 & $(0.49)$ & 0.09 \\
\hline Insurance & INSUR & 0.17 & $(0.38)$ & 0.15 & $(0.36)$ & 0.23 \\
\hline $\begin{array}{l}\text { Assets other than } \\
\text { savings account }\end{array}$ & ASS & 0.54 & $(0.50)$ & 0.49 & $(0.50)$ & 0.12 \\
\hline $\begin{array}{l}\text { Does not know interest } \\
\text { in credit card }\end{array}$ & INT_rate & 0.65 & $(0.48)$ & 0.51 & $(0.50)$ & 0.03 \\
\hline $\begin{array}{l}\text { Finds it difficult to pay } \\
\text { off credit card }\end{array}$ & PAY_off & 0.08 & $(0.27)$ & 0.21 & $(0.41)$ & 0.01 \\
\hline $\begin{array}{l}\text { Number of different } \\
\text { assets }\end{array}$ & NoASS & 0.82 & $(0.98)$ & 0.69 & $(0.86)$ & 0.06 \\
\hline
\end{tabular}

Table A6: IV Regressions Explaining Financial Behavior with Financial Literacy (FL) and Gender (FEM)

\begin{tabular}{ccccccc}
\hline & ASS & DEPO & INSUR & INT_rate & PAY_off & NoASS \\
\hline \multirow{2}{*}{ FL } & $0.840^{* *}$ & $0.771^{*}$ & $-1.242^{* * *}$ & -0.177 & $-1.373^{* * *}$ & $0.758^{*}$ \\
& $(0.386)$ & $(0.444)$ & $(0.064)$ & -1.449 & $(0.331)$ & $(0.435)$ \\
\multirow{2}{*}{ FEM } & 0.273 & 0.234 & $0.187^{*}$ & 0.298 & -0.462 & $0.284 * * *$ \\
& $(0.195)$ & $(0.190)$ & $(0.112)$ & $(0.273)$ & $(0.351)$ & $(0.010)$ \\
\hline Obs. & 412 & 414 & 414 & 128 & 126 & 412 \\
\hline Wald $\chi^{2}$ & 218.35 & 169.21 & 473.06 & 24.57 & 181.45 & 519.15 \\
Sargan/Hansen & $(0.000)$ & $(0.000)$ & $(0.000)$ & $(0.105)$ & $(0.000)$ & $(0.000)$ \\
& 0.308 & 1.385 & 2.440 & 4.689 & 2.990 & 0.418 \\
& $(0.998)$ & $(0.926)$ & $(0.786)$ & $(0.455)$ & $(0.702)$ & $(0.995)$ \\
\hline
\end{tabular}

Notes: The table reports coefficients and robust standard errors in parentheses. We use an IV Poisson regression model for NoASS, while all others estimates are from IV probit models. ***, ** and * denote significance at the 1\%, 5\% and 10\% levels, respectively. Financial literacy is measured by FK_DK_sum. Control variables explained in Tables 1-3 and Appendix, Table A7 - are lnY (log of income), ASS_h (high assets), ASS_m (medium assets), ASS_l (low assets), EDU_h (high education), RISK (risk aversion), BBKK (born in Bangkok), FEM (female), AGE, MARRIED, ECO (economics at school), EDU_m (mother has vocational training or higher), ADULT (number of adults in the household), SAVE (parents encouraged saving), POOR (economic background is poor), CHILD (number of children in the household). FL (financial literacy) is instrumented. Identifying instruments are ALLOW (allowance as a child), JOB (job before 15), BUDGET (parents taught to budget), FIN (financial understanding of parents), NUM (numeracy), and ACC (had a bank account before 18). The Wald $\chi^{2}$ test demonstrate that for five of the six estimated kinds of financial behavior the total influence of the regressors is highly significant $(\alpha<0.0001)$. The empirical significance level is presented in parentheses. The Sargan test proves the validity of instruments $\left(\mathrm{H}_{0}\right)$ applied in column ASS to PAY-off. The Hansen statistic is the GMM equivalent of the Sargan test used in column NoASS. Line Sargan/Hansen displays the test statistics. In parentheses the prob.value is presented. $\mathrm{If}_{0}$ is rejected this can be interpreted as indicating that at least one of the instruments is not valid. None of the six tests rejects $\mathrm{H}_{0}$. 


\section{Section A2: Explaining indicators of "good” financial behavior in Thailand}

When comparing financial behavior of men and women, it becomes clear that women do not display worse financial behavior. The survey asks respondents to give information on the amount and structure of savings as well as debt. In particular, we ask what form assets are held in and ask for detailed information on credit card debt. Based on this data we use indicators of more or less informed financial behavior which have been introduced in this specific form by Grohmann et al. (2014). Among these indicators, four refer to the asset side and two to credit card debt:

- The first indicator "assets other than savings account” refers to the situation in Thailand that almost everyone has a savings account. Beyond that, however, the use of further kinds of assets decreases dramatically so that about half of the middle class population sticks with just one or several savings accounts (see Table A5 above). There is no gender specific difference. Here we just present descriptive statistics, later on we also control for income and assets which naturally foster the use of other assets than savings accounts.

- The most common other asset is a "fixed deposit account", which in Thailand brings considerable tax benefits. Holding this kind of favorable asset is our second indicator of informed financial behavior. Interestingly, women tend to hold this kind of asset significantly more often than men, although the difference in absolute numbers with $44 \%$ to $38 \%$ is not too large.

- Thirdly, we look at the use of life-“insurance” products as a type of specific investment product. This savings product offers relatively low returns in Thailand compared to bonds, so that it cannot really be regarded as a good choice for informed customers. On the other hand life insurance offers payouts in case of early death and for this reason it can be interesting for risk averse people. Since women are in general rather more risk averse than men (e.g. Eckel and Grossman, 2008), buying life insurance may be particularly appealing to them, despite low financial returns.

- Turning to credit card debt, we ask whether one "does not know the interest on credit" (debt). Even though this is a knowledge question, and thus in a sense similar to knowing foreign banks, we here ask specifically about the interest paid on one's own credit card and not for abstract financial knowledge (32\% of women and 33\% of men own a credit card). Answers to this item are the sole case where women seem to be less informed than men. 
- One reason may be the next indicator of informed financial behavior, i.e. whether one finds it "difficult to pay off credit card" (debt). Women are a lot less likely to feel that paying off their credit cards is a burden. It hence follows that women are less likely to incur interest rate costs which may contribute to explaining why they are less likely to know the interest rate on their credit card.

- Beyond single products, we also consider diversification by simply counting the "number of different assets" a person owns. As before, obviously one needs to control for wealth. Nevertheless, the raw descriptive statistic is surprising because women hold significantly more different assets than men, despite lower income and assets.

In summary, and by just taking the raw numbers, we see that in three cases women demonstrate more informed behavior than men, according to our indicators. In one case women behave inferior and in two cases equal to men. All this does not show that women would lag behind men regarding the quality of financial behavior. 


\section{Section A3: Biographical characteristics of women and men}

In addition to standard socio-demographic and financial information, we also collected a number of indicators designed to give biographical information. These indicators have been used in earlier studies as documented in Grohmann et al. (2014). They cover various aspects of education and early experiences with money. They enable us to look in more detail at differences in family background and early life experiences with money between men and women in the sample. Descriptive statistics, again broken down by men and women are presented in Table A7. Results of $t$-tests are presented in the right most column.

(1) The first group of biographical characteristics addresses family background. When looking at these results father's and mother's education of men and women in our sample is significantly different, standing out among all the variables covered here. The result indicates that women that are part of Bangkok’s middle class where born to less educated parents than their male counterparts. In contrast to this strong difference, self-assessment regarding parents' understanding of financial matters and the economic background being poor are not significantly different between women and men.

(2) The second group contains variables on parental teaching. Parents usually taught their children to budget and encouraged children's saving. The frequency of this behavior is slightly higher for boys compared to girls but the difference in percentage points is not high and also not statistically significant.

(3) Another important biographical characteristic for later financial literacy is the education that children got at school. The subject "economics" is frequently taught as almost $67 \%$ of our participants had this subject at school. Women had economics in school more often than men, however, not to a significant degree. More men than women were born in Bangkok (marginally significant), although slightly more women received their highest educational degree in Bangkok.

(4) Finally, early experiences with money cover different aspects. Almost all participants had an allowance as children, so we do not consider this variable in our further examination. Slightly more than half had a bank account before the age of 18, equally likely among women and men. The last difference is that men are more likely to have had jobs before the age of 15 , this difference is significant, but only at $10 \%$. As most of our sample is university educated these jobs were clearly part-time work. Again, since middle class men tend to have had more educated parents, this is surprising. Possible answers to this puzzle are either that men, having 
grown up in Bangkok, felt poorer and so felt the need to get a part-time job, or that boys were more often allowed by parents to work (part-time) than girls.

Overall, most biographical characteristics do not differ significantly between women and men. What stands out, however, is the clearly higher education of men's parents compared to women's parents.

Table A7: Descriptive Statistics of Biographical Information, Broken Down by Gender

\begin{tabular}{lcccccc}
\hline & & \multicolumn{2}{c}{ women } & \multicolumn{2}{c}{ Men } & t-test \\
& acronym & mean & s.d. & mean & s.d. & p-value \\
\hline Family Background & & & & & & \\
\hline $\begin{array}{l}\text { Father has vocational training or } \\
\text { higher }\end{array}$ & EDU_f & 0.23 & $(0.03)$ & 0.33 & $(0.03)$ & 0.01 \\
$\begin{array}{l}\text { Mother has vocational training or } \\
\text { higher }\end{array}$ & EDU_m & 0.18 & $(0.03)$ & 0.25 & $(0.03)$ & 0.04 \\
$\begin{array}{l}\text { Financial understanding } \\
\text { of parents (1 -6) }\end{array}$ & FIN & 4.31 & $(1.59)$ & 4.46 & $(1.48)$ & 0.14 \\
$\begin{array}{l}\text { Considers economic background to } \\
\text { be poor }\end{array}$ & POOR & 0.25 & $(0.43)$ & 0.30 & $(0.46)$ & 0.10 \\
\hline Parental Education & & & & & & \\
\hline $\begin{array}{l}\text { Parents taught to budget (0-1) } \\
\text { Parents encouraged saving (0-1) }\end{array}$ & BUDGET & 0.81 & $(0.39)$ & 0.84 & $(0.36)$ & 0.19 \\
\hline Education at School & SAVE & 0.84 & $(0.36)$ & 0.88 & $(0.33)$ & 0.14 \\
\hline $\begin{array}{l}\text { Had economics at school } \\
\text { Was born in Bangkok }\end{array}$ & ECO & 0.69 & $(0.47)$ & 0.65 & $(0.48)$ & 0.19 \\
Highest educational degree in BKK & EDU_BKK & 0.88 & $(0.33)$ & 0.86 & $(0.35)$ & 0.29 \\
\hline Early Experiences with Money & & & & & & \\
\hline $\begin{array}{l}\text { Had allowance as a child } \\
\text { Had a bank account before 18 }\end{array}$ & ALLOW & 1.00 & $(0.06)$ & 0.99 & $(0.10)$ & 0.18 \\
Had a job before 15 & ACC & 0.57 & $(0.50)$ & 0.58 & $(0.49)$ & 0.37 \\
\hline JOB & 0.44 & $(0.50)$ & 0.50 & $(0.50)$ & 0.09 \\
\hline
\end{tabular}

Notes: Tables show data on early life experiences, broken down by gender. 
Section A4: Detailed information about the role of financial literacy and gender for financial behavior

This part extends Section A1 of the Appendix. Section A4.1 describes the empirical approach by which we analyze financial behavior and Section A4.2 shows the result when applying this approach to explain various kinds of financial decisions by instrumental variable (IV) regressions, including some modifications. Section A4.3 mentions further robustness checks.

\section{A4.1 Econometric approach}

Research has developed over the last ten years or so that is designed to increase our understanding of the role of financial literacy. Over the last years potential endogeneity of explanatory (right-hand-side) variables has been addressed by relying on instrumental variables which are often derived from childhood experiences of today's adults (Behrman et al. 2012). This leads to a wealth of variables which may be relevant when examining the role of financial literacy and raises the question of how to organize these variables.

So far, research either uses a limited number of variables (possibly determined by data availability) or imposes a two-step structure on the data. This structure distinguishes between variables that are seen as controls when the impact of financial literacy is analyzed, whereas other variables are used as instruments for financial literacy. There are good economic reasons for imposing such a structure and of course there are statistical tests to see whether conditions for the structure are fulfilled. Nevertheless, given the many potential influences, potential multicollinearity and possible endogeneity, we propose here a purely statistical-econometric procedure to decide which variables to use for which purpose.

In this paper we aim to explain financial behavior by relying on individual characteristics, in particular available socio-demographic information (Table 1) and biographical information (Table A7), and by also considering measures of financial literacy. In the presence of a long list of potential variables, but in the absence of clear theory on what the relevant variables for financial decisions are, we start the econometric analysis with the selection of individual characteristics that are relevant in a statistical sense. For this purpose least angle regression (LARS) is applied (Efron et al., 2004). This approach provides a compromise between forward and backwards regressions producing too small standard errors and, for example, the least absolute shrinkage and selection operator (LASSO, Tibshirani, 1996) where OLS coefficients are shrunk towards zero. 
According to the LARS-approach, among a collection of $m$ available covariates a parsimonious set for the efficient prediction of response variables is selected. Only $m$ steps are required. Each step adds one covariate to the model so that after $k$ steps just $k$ coefficients are nonzero. The procedure starts with all coefficients being equal to zero and finds the one predictor being most correlated with the response variable, say $x 1$. The largest step in the direction of this predictor is taken until some other predictor - say $x 2$ - has as much correlation with the current residual. LARS proceeds in a direction equiangular between the two predictors, $x 1$ and $x 2$, until a third predictor, $x 3$, earns its way into the "most correlated" set. LARS proceeds equiangularly between $x 1, x 2$ and $x 3$, that is, along the "least angle direction" until a fourth variable $x 4$ enters, and so on. Mallows' Cp (Mallows, 1973) is applied to find the best model involving a subset of all available predictors. Following the Cp criterion as the usual stopping rule within the LARS-approach, there are no more regressors incorporated when $\mathrm{Cp}$ reaches its smallest value. As $\mathrm{Cp}$ is an unbiased estimator of prediction error, the Cp minimization can be regarded as an unbiased estimator of the optimal stopping point.

The result of applying this LARS procedure to our data is presented exemplarily in Table A8, using the "number of different assets" as the dependent variable to be explained, as a proxy for informed financial behavior. Table A8 shows the stepwise outcomes of the LARS procedure, where the first variable being included is log of income, followed by asset variables and then already followed by financial literacy, whereas gender comes considerably later in step 11. Variables are included until step 18, i.e. 17 variables help to improve the estimation. The inclusion of further variables leads, however, to increasing $\mathrm{Cp}$ values. Following the LARS procedure these variables will not be included as control variables in the estimations.

As mentioned above, we present results here using the "number of different assets" as dependent variable. We argue that this variable is more representative for financial behavior than examining decisions about single assets or behavior towards credit card debt. In robustness checks we have calculated specific variable sets for each individual dependent variable, without major changes.

\section{A4.2 Explaining financial behavior}

Having revealed the set of useful variables that help our understanding of financial behavior, we now show regressions explaining all considered kinds of financial behavior by an instrumental variable (IV) approach. IV regressions seem advisable here as it is possible that financial literacy does not determine the choice and diversity of assets directly but rather 
causality works the other way around. Furthermore, bias caused by measurement error is also a possibility that can be addressed using IV regressions.

We hence look for variables that are correlated with the causal variable of interest, but uncorrelated with the error term, i.e. we need determinants that ensure the exclusion restriction. For this purpose we exploit the available biographical information (see Table A7). Some of these variables are not only indirectly correlated with the choice of asset types via financial literacy but also via other channels. In this event, the causal effect is not correctly recognized. We have found that allowance during childhood (ALLOW), persons who had a job before 15 (JOB), bank account before 18 (ACC), parents' understanding of financial matters (FIN), persons were taught to budget by their parents (BUDGET) and numeracy (NUM) can be used as identifying instruments as they do not directly affect our measures of financial behavior. These variables are excluded by the LARS procedure (see Table A7), and so do not influence the dependent variable directly, while economics as subject at school (ECO), saving between the ages of 12 to 16 (SAVE), poor economic background (POOR), mother's and father's education (EDU_m, EDU_f) are directly correlated with financial behavior. Among the six identifying instruments ALLOW and JOB are the only two that are excluded by LARS of financial literacy (not presented in the tables). From this view ALLOW and JOB could be suppressed as instruments. However, we prefer the approach with rather more than less instruments following Andrews (1999) and thus searching for the largest set of valid instruments.

The resulting second step-estimations are presented in Table A6 (see Appendix Section A1 above), where we cover only coefficients of the financial literacy variable and the gender variable. The coefficients of FL and FEM change only slightly if ALLOW is excluded as an instrument but added to the control variables (Table A9). The same follows if also JOB is suppressed as instrument (not presented in the tables). The Sargan-Hansen tests do not reject the validity of instruments. We do not show coefficients of the other 15 (control) variables in the second-stage regression (for information we also provide results of the first-stage regression to the main NoASS equation in Table A10 explaining financial literacy and for a probit estimation of NoASS, where this variable is substituted by a dummy in Table A11). Results show that financial literacy is a very important variable in explaining financial behavior: the coefficient signs are always as expected and statistically significant except for one case, the variable INT_rate (not knowing the interest rate on one's credit card). In contrast, gender of a person does not seem to be as important in explaining financial decision making, as coefficients are mostly insignificant. In one case women make worse decisions, 
they are more likely to buy life insurance (INSUR) and in another case they make better decisions, i.e. they diversify more (NoASS). Hence we do not claim that women show more informed financial behavior than men, but that they make equally good financial decisions.

\section{A4.3 Further robustness checks}

We shortly mention two further robustness checks: First, for completeness, we explain financial behavior within our general approach but without using the IV-regressions. Results in Table A12 show the coefficients of financial literacy and gender variables, whereas the other coefficients are hidden in order to save space. All of the financial literacy coefficients have the expected sign and three out of these six coefficients are statistically significant. Regarding the relationship between gender and informed financial behavior, women do not seem to make worse financial decisions than men, but ones in one case even better (ASS).

Second, we simply split the sample into women and men and then estimate the above introduced IV regression for both groups separately. The intention of this procedure is to consider that the gender variable also may have indirect effects via other characteristics like education or risk aversion on financial activities, which cannot be examined in the regressions in Table A6. Thus we allow for the slope coefficients of financial literacy and the control variables to be different in the groups of men and women, which may be seen as a generalization of Table A6. Results for the six observed kinds of financial decisions are shown in Table A13. We find that the coefficients on the financial literacy variable are mostly statistically significant and if so, they have the theoretically expected sign except for the PAY_off estimates of men. We see that the impact of financial literacy is not stronger for women than for men, reinforcing the earlier suspicion that it is not just financial literacy driving women's reasonable financial behavior. 
Table A8: Selection of Covariates by Least Angle Regression

\begin{tabular}{|c|c|c|c|c|c|c|c|}
\hline Step & Сp & $\begin{array}{c}\mathrm{R}- \\
\text { square }\end{array}$ & action & Step & Сp & R-square & action \\
\hline 1 & 441.6103 & 0.0000 & & 15 & 32.0953 & 0.5186 & + SAVE \\
\hline 2 & 243.5519 & 0.2371 & $+\ln Y$ & 16 & 24.0764 & 0.5305 & + POOR \\
\hline 3 & 167.5351 & 0.3296 & + ASS_h & 17 & 23.7685 & 0.5332 & + CHILD \\
\hline 4 & 113.1416 & 0.3965 & + ASS_l & 18 & $21.8348 *$ & 0.5379 & + MAR \\
\hline 5 & 98.1509 & 0.4166 & $+\mathrm{FL}$ & 19 & 22.1296 & 0.5399 & + EDU_f \\
\hline 6 & 81.5810 & 0.4386 & + EDU_h & 20 & 22.6294 & 0.5417 & + EDU_BKK \\
\hline 7 & 76.4345 & 0.4471 & $+\mathrm{AGE}$ & 21 & 24.3385 & 0.5420 & $+\mathrm{JOB}$ \\
\hline 8 & 71.7338 & 0.4550 & + BBKK & 22 & 26.1342 & 0.5423 & + ALLOW \\
\hline 9 & 69.2867 & 0.4603 & $+\mathrm{ECO}$ & 23 & 27.9304 & 0.5425 & + BUDGET \\
\hline 10 & 65.2648 & 0.4674 & + RISK & 24 & 29.1753 & 0.5434 & + FEM*RISK \\
\hline 11 & 50.7685 & 0.4870 & + FEM & 25 & 29.0459 & 0.5459 & + NUM \\
\hline 12 & 45.3234 & 0.4958 & + EDU_m & 26 & 29.7668 & 0.5475 & + FIN \\
\hline 13 & 38.7300 & 0.5060 & + ASS_m & 27 & 31.5191 & 0.5478 & $+\mathrm{ACC}$ \\
\hline 14 & 36.4903 & 0.5110 & + ADULT & 28 & 28.0000 & 0.5543 & + AGEsq \\
\hline
\end{tabular}

Notes: The table shows Mallows $\mathrm{Cp}, \mathrm{R}^{2}$ and the independent variables selected to explain the dependent variable, the number of different assets held (NoASS). The independent variables selected to explain NoASS are referred to as "actions" of the least angle regression. In the following tables all variables from step 2 to 18 are incorporated as regressors. Financial literacy is measured by FL_DK_sum.* indicates the smallest value for Cp. The acronyms are explained in Tables 1-4. The following additional variables were considered here: EDU_h (=1 if education is high, bachelor degree or higher), FEM (=1 if female), FEM*RISK (interaction variable between FEM and RISK) and AGEsq is $\mathrm{AGE}^{2}$.

Table A9: Alternative IV Regressions Explaining Financial Behavior with Financial Literacy (FL) and Gender (FEM)

\begin{tabular}{lcccccc}
\hline & ASS & DEPO & INSUR & INT_rate & PAY_off & NoASS \\
\hline FL & $0.841^{* *}$ & $0.767^{* *}$ & $-1.240^{* * *}$ & -0.177 & $-1.288^{* * *}$ & $0.885^{* *}$ \\
& $(0.385)$ & $(0.397)$ & $(0.058)$ & $(0.938)$ & $(0.454)$ & $(0.383)$ \\
FEM & 0.273 & & $0.189^{*}$ & 0.298 & -0.518 & 0.232 \\
& $(0.195)$ & $(0.188)$ & $(0.117)$ & $(0.279)$ & $(0.357)$ & $(0.195)$ \\
\hline Obs. & 412 & 414 & 414 & 128 & 124 & 412 \\
Wald $\chi^{2}$ & $220.15^{* * *}$ & $154.97 * * *$ & $530.92^{* * *}$ & 18.34 & $48.58^{* * *}$ & $519.79 * * *$ \\
\hline
\end{tabular}

Notes: The table reports coefficients and robust standard errors in parentheses. We use an IV Poisson regression model for NoASS, while all others estimates are from IV probit models. ***,** and * denote significance at the $1 \%, 5 \%$ and $10 \%$ levels, respectively. Financial literacy is measured by FL_DK_sum and instrumented. As identifying variables are chosen those as in Table A6, excluding ALLOW but added as a control variable because a priori it is not obvious whether this variable correlates with saving at a young age (SAVE) and economic background (POOR) so that allowance during childhood may have an indirect impact on financial behavior not only via financial literacy. The Wald $\chi^{2}$ test shows whether the total influence of the regressors is significant. If $\mathrm{H}_{0}$ is rejected this can be interpreted as an acceptable specification. This is the case in five of six estimations. 
Table A10: First-stage Estimation of NoASS Equation in Table A6 Explaining Financial Literacy

\begin{tabular}{lrlrl}
\hline & Coef. & Std.Err. & $\mathrm{z}$ & $\mathrm{P}>|\mathrm{z}|$ \\
\hline $\ln Y$ & 0.191 & 0.156 & 1.22 & 0.221 \\
ASS_h & 0.507 & 0.213 & 2.38 & 0.017 \\
ASS_m & 0.370 & 0.158 & 2.34 & 0.020 \\
ASS_l & 0.257 & 0.129 & 1.99 & 0.047 \\
EDU_h & 0.045 & 0.110 & 0.41 & 0.685 \\
RISK & -1.131 & 0.217 & -5.20 & 0.000 \\
BBKK & 0.025 & 0.094 & 0.26 & 0.792 \\
FEM & 0.111 & 0.082 & 1.34 & 0.181 \\
AGE & -0.001 & 0.006 & -0.13 & 0.898 \\
MAR & -0.149 & 0.103 & -1.44 & 0.150 \\
ECO & 0.117 & 0.122 & 0.96 & 0.338 \\
EDU_m & 0.056 & 0.036 & 1.52 & 0.128 \\
ADULT & -0.059 & 0.028 & -2.06 & 0.039 \\
SAVE & 0.280 & 0.135 & 2.07 & 0.038 \\
POOR & 0.046 & 0.093 & 0.50 & 0.619 \\
CHILD & 0.029 & 0.045 & 0.65 & 0.519 \\
ALLOW & 0.042 & 0.787 & 0.05 & 0.958 \\
JOB & -0.005 & 0.094 & -0.05 & 0.957 \\
BUDGET & 0.110 & 0.144 & 0.76 & 0.446 \\
FIN & 0.012 & 0.032 & 0.36 & 0.719 \\
NUM & 0.127 & 0.055 & 2.31 & 0.021 \\
ACC & -0.096 & 0.093 & -1.02 & 0.306 \\
_Cons & -1.194 & 0.970 & -1.23 & 0.218 \\
& & & &
\end{tabular}

Notes: The table reports coefficients, robust standard errors, z statistics and prob. values. The acronyms are explained above. 
Table A11: Complete Probit IV Estimation of D_NoASS Explaining Financial Behavior with Financial Literacy

(FL) Gender (FEM)

\begin{tabular}{lcccl}
\hline \multicolumn{1}{c}{ Variable } & coef. & std.dev & $\mathrm{t}$ & prob.value \\
\hline FL_DK_sum & 0.276 & 0.173 & 1.59 & 0.112 \\
lnY & 0.158 & 0.081 & 1.95 & 0.051 \\
Ass_h & 0.023 & 0.136 & 0.17 & 0.864 \\
Ass_m & 0.032 & 0.097 & 0.34 & 0.736 \\
Ass_l & -0.175 & 0.078 & -2.25 & 0.025 \\
EDU_h & 0.062 & 0.058 & 1.07 & 0.286 \\
RISK & 0.114 & 0.245 & 0.47 & 0.640 \\
BBKK & 0.076 & 0.050 & 1.51 & 0.131 \\
FEM & 0.080 & 0.049 & 1.62 & 0.106 \\
AGE & 0.009 & 0.004 & 2.69 & 0.007 \\
MAR & 0.097 & 0.064 & 1.53 & 0.127 \\
ECO & 0.101 & 0.063 & 1.60 & 0.111 \\
EDU_f & 0.045 & 0.022 & 2.01 & 0.045 \\
ADULT & 0.017 & 0.018 & 0.97 & 0.334 \\
SAVE & -0.005 & 0.094 & -0.05 & 0.958 \\
POOR & -0.019 & 0.053 & -0.35 & 0.724 \\
CHILD & -0.045 & 0.025 & -1.81 & 0.071 \\
_cons & -0.623 & 0.261 & -2.39 & 0.017
\end{tabular}

Notes: In this probit estimation the number of assets (NoASS) is replaced by a dummy (D_NoASS) , where D_NoASS $=1$ if NoASS $>0$. All other things are the same as in Table A6, column NoASS. The table reports coefficients and robust standard errors in parentheses. ***, ** and $*$ denote significance at the $1 \%, 5 \%$ and $10 \%$ levels, respectively. 
Table A12: Explaining Financial Behavior with Financial Literacy (FL) and Gender (FEM)

\begin{tabular}{lcccccc}
\hline & ASS & DEPO & INSUR & INT_rate & PAY_off & NoASS \\
\hline $\begin{array}{l}\text { Expected sign } \\
\text { of FL coefficient }\end{array}$ & + & & & & & + \\
\hline F L & $0.227^{* * *}$ & 0.153 & $-0.273^{* *}$ & -0.366 & -0.256 & $0.222^{* *}$ \\
& $(0.085)$ & $(0.104)$ & $(0.127)$ & $(0.237)$ & $(0.240)$ & $(0.098)$ \\
FEM & $0.396^{* * *}$ & 0.424 & 0.171 & 0.815 & -0.485 & 0.325 \\
& $(0.151)$ & $(0.357)$ & $(0.349)$ & $(0.784)$ & $(0.776)$ & $(0.254)$ \\
& & & & & & \\
\hline Pseudo-R & 0.335 & 0.225 & 0.368 & 0.162 & 0.221 & 0.242 \\
Obs. & 433 & 435 & 435 & 135 & 133 & 433 \\
\hline
\end{tabular}

Notes: The table reports coefficients and robust standard errors in parentheses. We use a Poisson count regression model for NoASS, while all others estimates are from probit models. ***, ** and * denote significance at the $1 \%$, $5 \%$ and $10 \%$ levels, respectively. Financial literacy is measured by FL_DK_sum. Control variables - explained in Tables 1-5 - are lnY (log of income), ASS_h (high assets), ASS_m (medium assets), ASS_l (low assets), EDU_h (high education), RISK (risk aversion), BBKK (born in Bangkok), FEM (female), AGE, MARRIED, ECO (economics at school), EDU_m (mother has vocational training or higher), ADULT (number of adults in the household), SAVE (parents encouraged saving), POOR (economic background is poor), CHILD (number of children in the household), FL (financial literacy).

Table A13: IV Regressions Explaining Financial Behavior with Financial Literacy (FL) for Women

\begin{tabular}{|c|c|c|c|c|c|c|}
\hline & ASS & DEPO & INSUR & INT_rate & PAY_off & NoASS \\
\hline FL & $\begin{array}{c}1.024^{* * *} \\
(0.339)\end{array}$ & $\begin{array}{c}1.049 * * * \\
(0.198)\end{array}$ & $\begin{array}{c}-1.304^{* * *} \\
(0.098)\end{array}$ & $\begin{array}{c}0.372 \\
(1.232)\end{array}$ & $\begin{array}{l}-0.528 \\
(2.963)\end{array}$ & $\begin{array}{c}0.634 \\
(0.521)\end{array}$ \\
\hline Obs. & 194 & 195 & 195 & 61 & 52 & 194 \\
\hline
\end{tabular}

Table A13: Continuation - for Men

\begin{tabular}{|c|c|c|c|c|c|c|}
\hline & ASS & DEPO & INSUR & INT_rate & PAY_off & NoASS \\
\hline FL & $\begin{array}{l}1.075 * \\
(0.665)\end{array}$ & $\begin{array}{c}1.197 * * * \\
(0.218)\end{array}$ & $\begin{array}{c}-1.223 * * * \\
(0.088) \\
\end{array}$ & $\begin{array}{c}-1.864 * * * \\
(0.189) \\
\end{array}$ & $\begin{array}{c}1.735^{* * *} \\
(0.237) \\
\end{array}$ & $\begin{array}{c}0.360 \\
(0.347)\end{array}$ \\
\hline Obs. & 218 & 219 & 219 & 67 & 73 & 218 \\
\hline
\end{tabular}

Notes: The table reports coefficients and robust standard errors in parentheses. We use a GMM Poisson estimation for NoASS, while all others estimates are from IV probit models. ***, ** and * denote significance at the $1 \%, 5 \%$ and $10 \%$ levels, respectively. Financial literacy is measured by FL_DK_sum. Control variables are lnY (log of income), ASS_h (high assets), ASS_m (medium assets), ASS_l (low assets), EDU_h (high education), RISK (risk aversion), BBKK (born in Bangkok), AGE, MARRIED, ECO (economics at school), EDU_m (mother has vocational training or higher), ADULT (number of adults in the household), SAVE (parents encouraged saving), POOR (economic background is poor), CHILD (number of children in the household. FL (financial literacy) is instrumented. The identifying instruments are ALLOW (allowance as a child), JOB (job before 15), BUDGET (parents taught to budget), FIN (financial understanding of parents), NUM (numeracy), and ACC (had a bank account before 18). 